\title{
ACQUISITION AND REVERSAL OF A TWO MANIPULANDA DIFFERENTIATION IN SHAM, NEOCORTICALLY, AND HIPPOCAMPALLY LESIONED RATS
}

By

MICHAEL ARNOLD MILAN

\begin{abstract}
A DISSERTATION PRESENTED TO THE GRADUATE COUNCIL OF
THE UNIVERSITY OF FLORIDA

IN PARTIAL FULFILLMENT OF THE REQUIREMENTS FOR THE DEGREE OF DOCTOR OF PHILOSOPHY
\end{abstract}

UNIVERSITY OF FLORIDA 


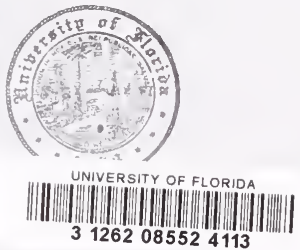




\section{ACRTOKIDDGEIFTS}

I gratefully acrnonledge the support and direction prorided by Dr. H. S. Pennypacier both in the execution of the present project and, more 1aportantiy, throughout by gradnate carear.

I also express ey appreciation to Dr. Robert I. Iseacson, Dr. Frederick A. King, Dr. C. Michael Levy, and Dr. Hilse B. Webb for thelr assistance in the development of this dissertation.

I thank Mrs. Pauletta Sanders and Mrs. Gloria Snlth for their histolorical assistance, and Mrs. Irma Snith who ably typed the present manuscript. 
TABIE OF COHTENTS

Page

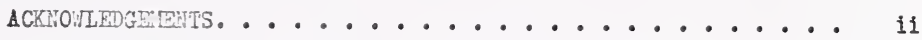

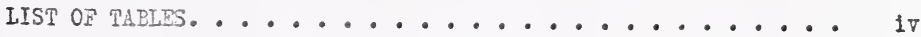

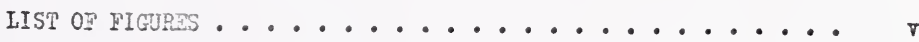
AESTRACT. ..........................

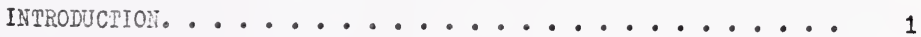

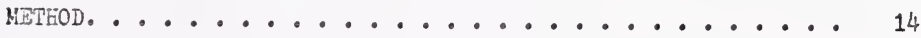

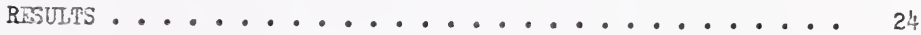
DISCussiol. ........................... 47

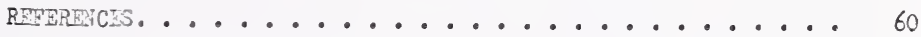
BIOGRAPHCAI STETCH .................... 67 


\section{LIST OP TABLES}

Teble

1. TRIATS TO CRITERIOU IN ACQUISITTOU ATD RETPRSAT FOR SHAH, NEOCORICALIY, ATI HIPPOCAYPALIY LESIONDD SS ASSIGIED TO THE REITYORCZD RESPONSES EOUUTED

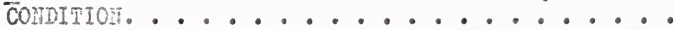

2. TRIAIS TO CRITRETON IN ACQUISITION AND RETEPSAJ FOR SEAM, NEOCORTICAILY, AYD HIPPOCAMPAILY LESIONED SS ESSIGIDT TO THE NOH-RINTORCED RTSPOISTS EQZUATRD

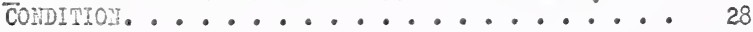

3. SPEAEIAN RATK ORDYR CORPTAATION COEFPICIENTS $\left(r_{S}\right)$ FOR SHAM, NZOCORTICAI, AND HIPFOCEIPII IESION GROUPS • •

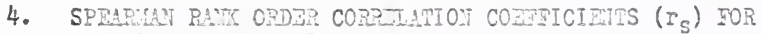
SHM, NEOCORTICAI, AMD RIPFOCARPA LESION GROUPS UNDER ENUATAD REINARCAD OR NOH-RRIRIORCED RESPONDING DURING TRAIMING . . . . . . . 31

5. ANLLYSIS OF VARIATCE ON TRIATS TO CRITERTON . . . . 37

6. ATHLYSIS OF TARIANCE OH SOUAREROOT TRATSFORATION OF

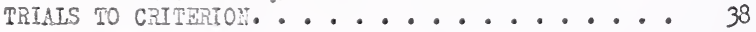

7. STUDHTIZED RANGE STATISTIC A POSTERIORI TESTS..... 46 


\section{IIST OF FIGURSS}

Figure

Page

1. Tracings of representative cross sections througin the hippocampal lesion.

2. Tracings of representatire cross sections through the neocortical lesion.

3. Lumber of sessions for Ss in each lesion group to attain criterion in acquisition: Reinforced responses equated

4. Nunber of sessions for $\mathrm{S}$ in exch lesion group to attain criterion in reversal: Reiniorced responses equated.

5. Number of sessions for $S$ in each lesion group to attain criterion in acquisition: Non-reinforcel responses

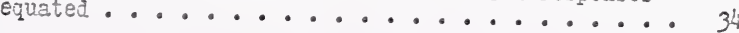

6. Number of sessions for $S S$ in each lesion group to attain criterion in reversal: Non-reinforced responses

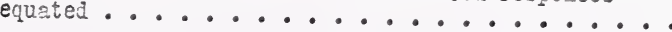

7. Cumlative percentage of $S$ in each lesion condition attaining criterion in successive 5 session blocks.

8. Cumulative percentage of $S \mathrm{~S}$ in each response-reinforcement condition attaining criterion in successire 5 session

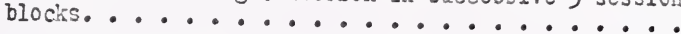

9. Cumlative percentage of Ss attaining criterion in aquisition and reversal in successive 5 session

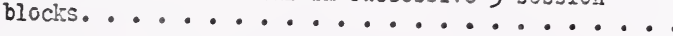

10. Cumulative percentaze of $S$ s in each lesion condition attaining the acquisition criterion in successive 5 session

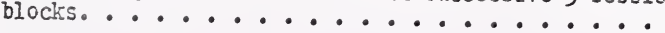

11. Curulative percentage of Ss in each lesion condition attaining the reversal criterion in successive 5

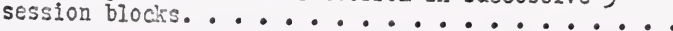

12. Mean trials to criterion in acquisition and reversal for

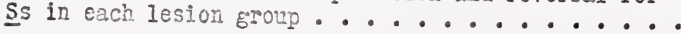


Abstract of Dissertation Presonted to the Graduate Council in

Partial Fulfillment of the Requirements for the Dezree of

Doctor of Philosophy at the University of Florida

ACQUTSITION AUD REVRRSAT, OF A THO MANIPULAPDA DIFPERTHTIATION IN SHAH, NEDCORTICALIY, ATD HIPFOCAPRALLY LESIOIED PATS

By

Michael Arnold Hilan

June, 1970

Chairuan: H. S. Pennypacier

Major Departuent: Psychology

Sham, neocortically, and hippocampally lesioned rats vere examinet in the acquisition of a two anhpulenta differentiation under conditions which insured that either the absolute number of reinforced. or non-reinforced responses each $\mathbf{S}$ exitted on each panipulandu during eaci experlnental session were equated. Acquisition performance was not differentially afiected by the three lesions, nor by equated reinforced or non reinforced responding. Reversal periormance did not differ for the neocortically and hippocampally lesioned Ss, but both appeared to be facilitated when coapared to sham control Ss. As in acquisition, equated reinforced or non-reinforced responding did not differentially affect perforance of the three lesion groups. 
INTRODUCTIOY

The hippocampus, nestled in the inner folds of the temporal lobe, has been subjected to more intense experimental intestigation within the past decade than in all previous years combined (after Douglas, 1967). The early neurvanatomical investifations of Papez (1937) wich first linked the paleocortical structures of the rinencephalon with emotional behavior were supported by the contenporary experimental investigations, performed by Kluver and Bucy (1939), of the effects of temporal lobectony on beharior. Mactean (1954, 1955, 1957, 1958) fordalized this orientation, postulating a dichotony between the phylogenetically older paleocortex ard the more recent neocortex. The former was prosented as involved in a. variety of enotional and visceral functions, wile the latter was thought to be-concerned with more cognitive functions. Howerer, as the hippocampus was subjected to more intense experimental investigation a more complex picture of hippocampal function energed. Before sumarizing the results of more recent investigations of the role of the hippocampus in behavior and, concurrently, reviewing the physiological theories of hippocampal function which have emerged from those data, a general description of the hippocampus and its' interconnections with other brain structures will be provided.

The hippocanpal formation, composed of the hippocampus (Ammon's horn), the hippocampal grus, the fascia dentata and the fornix, lies along the medial and ventral border of the temporal lobe where it is wrapped 
around the posterior surface of the thalamus. The hippocampus, reminiscent of the common sea horse Hionocamous hidoocampus from which its name is derived, is the major structural component of the hippocampal forwation. Gross description of the hippocampus was provided by Iorente de No (1934, cited in Douglas, 1967) who divided it into four seguenis: CA1, located proximal to the subiculum, CA2, CA3, and CA4, Iying in the fold of the granule cell layer of the fascia denteta. The nost generally accepted cytoarchitectonic description of the conplex internal structure of the hippocempus was provided by Cajal (1955). Starting from the ventral surface above CA2, then proceading vertically, seven rajor layers are evident: the ventricular ependyas, alveus, stratum oriens, stratum pyranidale, stratur radiun, stratum lacunosu, and stratum noleculare. A detailed exposition of the internal morohology of the hippocampus and hippocampal formation is provided by Heissner (1966).

Two najor afferent pathwajs serve the hippocampus: the alvear path through the fornix systed and the perforant path through the subicu1um. The fibers of the fornix arise primarily in the septal area and the intralaminar nuclei of the thalamus (Green \& Adey, 1956). The system is more involved than this, however, for inputs also reach the hippocampus from the ascending reticular activating system of the midbrain and thalezus (Green \& Arduini, 1954) and from the hypothalamus as well (Feldnan, 1962). The perforant path reaches the hippocarpus by way of the entorhinal cortez and subiculum. The temporoamonic tracts pass from the entorhinal cortex through the subiculum to the hippocampus proper. The entorhinal cortex, in turn, receives its afferents from considerable areas of the neocortex (Green, 1964). In addition, there is 
evidence for direct fibers frod the cingulu attaining the hippocandis via the parforant pathray (Adey, 1961).

Fibers passing into the fimbria constitute the main efferent pathway of the hippocampus. These fibers cross to the contralateral hippocampus via the hippocanpal comissure, or enter the fornix and project variously to the septun, hypothalams, anterios thalamus, and rostral portions of the brain stem (Green \& Adey, 1956). The hippocampus also gives rise to efferent fibers to the entorhinal area via the temporoanonic pathiay. In addition, Gloor (1960) presents eridence for primary hippocampo-amygdeloid fibers as well as secondary amygdalohippocampal connections. An intensive revien of the literature pertain ing to the neuroanatomical investigation oi the hiopocanpal aiferent and efferent systems may be found in Green (1954) and Stumps (1965).

In an attempt to assess the contribution of the hippocenpus to the physiological substrata of beharior, researchers have examined the effect of hippocampectomy upon a wide rariety of behaviors. One of the most studied classes of behavior falls under the general notation of aroidance conditioning. Interest was sparked in this paradign by the relatively early study of Kimura (1958) who found that rats with bilateral posterior hippocempal lesions were deficient when compared to neocortically lesioned and shan operated subjects ( $\underline{S}$ ) in their ability to withold a well-practiced, food motivated approach response following the introduction of punishment (electric shock) of the consumatory response. The essential characteristics of this experimental paradigm are prototypic of what is generally referred to as passive aroidance conditioning. Such deficits in passive aroidance hare since been replicated under 
varying conditions in numerous studies (e.8. Isascson \& Vichelgren, 1962; Kinble, 1963; Teitelbaum \& Nilner, 1953). Those studies thich have failed to replicate these findings have reported restricted lesions involving onjy the dorsel portion of the hippocempus (Boitano \& Iscacson, 1966; Krein, Scterliev \& Kaada, 1964), or have eaployed a response of lov probability (Kinble, Kirkby \& Stein, 1966; Vinocur \& Uills, 1969). It is possible to construct various cxplanations of the underlying nature of the observed hippocanpectony-induced deficit; one such suggestion is that hippocamal lesions in sone way vitiate the aversive effect 0 f the punishing stimulus. Such a position vould lead to the prediction that hippocanpectomized Ss would be deficient in a vide range of shock notivated bohavions. This does not anpear to be the case, hoverer, for hipposapectonized Ss are not necessarily retarded when compred to control Ss in their ability to raster a variety of active aroidance tasks.

In the typical one-way active avoidance paradign $S \mathrm{~S}$ is required to wove from one compartient of a shuttlebox to a second in the presence of a varning signal to aroid an aversite stimulus is delivered and $\mathbf{S}$ must then perforn the response in order to escape from it. Following coupletion of the trial $\underline{S}$ is returned to the original compartment of the shuttlebox and the procedure repeated. Although Miki (1962) reported that destruction of the hippocampus had no effect on this variation of aroldance conditioning, more recent inrestigations have indicated that there is 3 lesion-induced deficit wich, honever, appears to be of a lesser relative magnitude than that found in the passire aroidance paradign (Kcliou \& Thompson, 1966; 01.ton \& Isaacson, 1967). 
If the above aroldance paradign is modified so that $\underline{S}$ is not returned to the original compartment of the shuttlebox following each trial but instead cust return to it as the response in the following aroidance trial the tasir is retermed two-bay active aroidance. When compared to neocortically lesioned and sham operated Ss, hippocampectomized Ss appear to be facilitated in the accuisition or this response (Isaacson, Douglas \& Hoore, 1961). It has been suggested that facilitation is due to the presence of a passive aroidance component involved in the twoway active aroidance paradign which interieres with acquisition in control $\underline{S}$ ( $\underline{S}$ is required to return to the conpartment which has most recently been associated with aversive stimulation). Hippocampectonized Ss which have been denonstrated to be relatively inpervious to the effect of the contingencies necessary for the instatenent of the passive avoidance response are not so haripered and consequently acquire the two-tay active aroidance response arore readily (Douglas, 1967). The slight deficit seen in the hippocampectomized Ss' acquisition of the oneray active aroidance task can also be related to the deficit hippow carpectorized Ss manifest in passive avoidance. Here, however, the hippocampectomized $\underline{S}^{\prime}$ tendency not to aroid the compartment associated with aversive stimulation retards acquisition relative to control Ss (Olton \& Isaacson, 1967).

A secona formulation of the underlying nature of the hippocampal contribution to behavior which, like the aversive stimulus position, relates to the passire avoidance deficit suggests that hippocanpal lesions enhance the reinforcing properties of appetitive stimuli or, 
alternatively, holds that the hippocarpel lesion in soje fashion elevates drive level relative to non-hippocanpectomized Ss under equal levels of deprivation. Jarsard (1968) has uriefly revieved the literature which supports this position and points out that in addition to the intimate connections of the hippocaipus vith structures luportant for physiological homeostasis, beharioral evidence Indicates that hippocanpectonized Ss are more active in both novel and non-novel situations, increase their response rate for food and water, and show slower extinction of a food. rotivated running response. Although hippocenpectonized Ss have not been found to eat gore food than control Ss, they hare been found to dring more vater. It has been argued that the increased drive hypothesis has generally been abardoned (Douglas, 196?). Hovever, the arguments Earshalled against this position have stressed the findings of the aroidance conditioning paradigms and reasoned that because hippocanpectonized Ss do not appear to be more sensitire to the drivem inducing properties of arersive stimuli than do intact $\underline{S}$, it is inappropriate to posit that the reinforcing or drive reducing properties of appetitive stimuli might differentially affect hippocarpectomized and norcal Ss. Such a critique is cogent only if the theorist holds that a unitary or one-process theory of hippocampal function will explain the whole spectrun of lesion-induced behavioral anomalies. Whether it is possible to formulate a one-process theory of hippocanpal function has jet to be demonstrated.

The deficit seen in the passive avoldance performance of hippocampectomized Ss has also been tieved as a manifestation of a general tendency towards response perseveration or, alternatively, an inability to inhibit responses. A considerable body of evidence is available in support of such a position. Correll (1957) found that cats subjected 
to bilateral hippocampal stirulation during the acquisition and extinction of a food-motivated straight alleyway running response showed no difference in rate or acquisition when compered to control ss but did require a greater number of trials in extinction. This finding has been rellably replicated in rats following hippocampal destruction (Jarsard \& Isaacson, 1965, Rapholson, Isaacson \& Douglas, 1966). A closer examination of the phenomenon indicates that the interval between extinction trials is an important variable to be considered, for while the increased resistence to extinction is deronstrable when trials are spaced, the hippocampal lesion deficit disappears in the wassed presentation of the extinction trials (Jarrard \& Isaacson, 1965; Jarrard, Isaacson \& wickelgren, 1964). Both Peretz (1965) and Douglas and Pribram (1966) have reported that hippocanpectonized Ss show shorter response latencies and a greater number of responses to extinction than do control Ss. Increased resistance to extinction has also been deanonstrated in the two-vay active avoidance paradign (Isacson, Douglas \& Moore, 1961).

However, Schmaltz and Isaacson (1967) have presented slightly divergent findings concerning the performance of hippocanpectomized Ss in extinction. They ran hippocanpally lesioned and control Ss to complete extinction in as many 30-minute free operant sessions as were required for the attaiment of their siringent criterion. No difference was found between the experimental and control $\underline{S}$ in the total number of sessions required for extinction. In addition, the hippocampectomized $\underline{S}$ showed shorter response latencies in only the first extinction session; no differences between groups vere found for any of the subsequent sessions. 
Kaplan (1967) has reported that hippocanpectomized Ss show faster exinction of a freezing reaction taken as indicative of a classically conditioned emotional response.

The general inability of hippocanpally lesioned $\underline{S}$ s to inhibit responses has been videly dezonstrated in a number of other situations. Elen and Vilson (1963) found hippocampectonized rats imparea in their ability to inhibit one type of bar press and alopt a second follcuing a change in the response requirements for reinforcement. Both Nizi (1965) and Stanson and Isaacson (1967) have denonstrated a hippocampal lesion-induced deficlency in yielding to stinulus control following the initiation of $S^{D}-S \Delta$ training. Fovever, the latter authors also deanstrated that hippocempectonized Ss could radily acquire the discrimination provided they were not subjected to a long past history of continuous reinforcement for responding prior to the initiation of discrimination training. Clar's and Iseacson (1965) found that hippocampectonized Ss vere less efficient than control Ss on DRU schedules of reinforcenent. A follow-up study by Schraltz and Isascson (1966) presented findings analogous to those of Clark and Isaacson (1965), inaicating that hippocazpally lesioned Ss could perforr well on DRL schedules if not first subjected to prolonged crî training.

The apparently critical role of past learning in the demonstration ô hippocanpal lesion-induced deficits in discricination and DRL performance suggested to sone that the hippocampus was not involved in the inhibition of behavior in general, but was more specifically necessary for the inhibition of well practiced responses. The denonstrations by Kimble, Kirkby and Stein (1966) and Winocur and Mills (1969) that 
hippocampectomized Ss showed no deficit in their ability to inhibit an unlearned escape response froy a smell, elevated perch when the response vas punished lead to their formal stategent of that position. Hovever, Isaacson, Olton, Bauer and Swart (1966) and Teitelbaum and Milner (1963) have presented contradictory data, indicating that hippocanpectomized Ss are deficient in withholding a naturally occurring response involving a stepudom from a platforn to an electrified grid. The former authors, who shook the platforn to increase the probability of response occurrence, suggested that the escape response employed by Kirole, Kirkby and stein (1966) was too weak or inprobable in nature to adequately reveal a hippocarapal lesion-induced deficit.

Inhibitory deficits of hippocanpectomized Ss have also been widely examined within the context of exploration and spontareous alternation paradigns. Roberts, Denoer and Broduick (1962) compared exploration rates of hippocanpectorized and control SS in T- and Yamazes and found no differences in initial rates, but a more rapid decrease in exploration rate in control than in lesioned Ss. An additional analysis revealed that Ss with small hippocampal lesions shoied a moderately, but significant, slower exploration rate decrease than controls, and that $\underline{S}$ with massive hippocanpal destruction showed no rate decrease whatsoever. Leaton (1965) studied opportunity for exploration as a reinforcer of a T-maze turning response and found evidence for acquisition in norval and sham operated $\underline{S}$ while hippocanpectonized Ss were unable to overcone perseverative tendencies and consequently sho:ed no acquisition effect. Forced training was instituted in the second phase of the experiment and measures of running specd were taken. The hippocanpectomized ss showed slower habituation to the reinforcer, indexed by a slower decline in 
running speed over trials than control Ss. Kirkby, Stein, Kinble and Kimble (196\%) examined perseveration of a T-maze response as a function of goal-box confinement. Whth short confinement periods (50 seconds) hippocampal lesioned Ss showed perseverative behavior while control Ss spontaneously alternated their responses on successive trials. With longer confinement periods (10 and 50 minutes) both hlppocampectomized and control Ss denorstrated spontaneous alternation. A supplementary analysis revealed hippocampectonized S $5^{\circ}$ perseverate responses Der se rather than responses to specified locations.

Studies of the effect of hippocanpal lesions upon taze learning have yielded rathor consistent results. In general, the hippocampal lesion-induced dêicit is slight, if present at 2.11 , in very simple razes, but as aaze complexity increases the lesion-induced deficit in acquisition becomes increasingly more manifest. These findings have been attributed to the hippocampectorized Ss' inability to inhibit the reentry of previously explored blinds and the ereater frequency of blinds in progressitely more complex mazes (Kaada, Pasmussen \& Kvie, 1961 ; Kimble, 1963; Kimble \& Kiable, 1965). Hosteller and Thomas (1967) have demonstrated that the hippocampal deficits in aaze learning cannot be attributed to enhanced thigrotaxis. The hippocempal lesion-induced changes in spontaneous alternation and maze performance suggested to Kimble and his comorkers (Kimble, Kirzby \& Stein, 1966; Kirkby, Stein, Kimble \& Kimble, 1967) that hippocanpectonized Ss suffer from a reduced rate of infornation acquisition. This position is incomplete, hovever, for it fails to account for the unimpaired acquisition rates hippocanpectomized Ss demonstrate in alternative leaming paradigms. 
Although hippocanpectomized Ss appear deficient in their ability to withhold responses in successive or gomo go discrimination problens (Kimble, 1963), numerous studies have deconstrated that they do not differ from control Ss on a vide valiety of simltaneous discrimination problems (Allen, 1940, 1941; Brokn, Kaûnan \& Varco, 1969; Grastyan \& Karmos, 1962; Hirano, 1966; Kimble, 1963; Kimble \& Zack, 1967; Swann, 1934, 1935; Teitelbaun, 1964; Webster 8: Voneida, 1964). When hippocampectonized Ss are required to reverse such a discrimination, a. pronounced deficit in shifting responding from that which was previously reinforced to that which is nenly reinforced is regularly observed (Brom, Kaufman \& Narco, 1969; Kimble \& Kimble, 1965; Rabe, 1963; Stutz \& Rocklin, 1968; Swanson \& Isaacson, 1967; Teitelbaum, 1964; Thompson \& Langer, 1963).

In an attempt to explain the changes observed in positively reinforced bohavior following hippocampectomy in teras of the loss of a single process contributing to such behavior in the intact organisn, Douglas and Pribram (1966) developed a sophisticated neurophysiological theory of "problen solving." Although the authors were initially concerned with the hippocamus, they found it necessary to include in their theory a second limbic system structure, the anygdala, in order to account for the behavior of which hippocampectonized Ss are capable. Each of these structures is postulated to be intirately involved in two distinct processes underlying problen solving or discrimination learning: the hippocampus-centered "error-evaluate" process and the complementary amygdala-centered "reinforce-rezister" process. The terms are indicative of the function of each: the reinforce-register process is depicted as 
increasing the future probability of a response winch has been followed by reinforcenent; the error-ovaluate process is postulated as decreasing the future probability of a response which has not been followed by reinforcement. During discrimination learning in the intact organisu both these processes or systens are cooperative as behavior is brought under stimulus control.

The proposed neuronal system urderlying the erpormevaluate process intoltes hippocempally mediated inhibition in a Renshavolike mechanisn within afferent systems which serves to "gate out" nonreinforced stimuli. In the absence of the hippocampus non-reinforcenent cannot aiter bohavior and discrimination learning must be accomplished by the remaining reinforcenegister systea. The effect of reinforcement terued "inpellence" is increantal over reinforced training, constant in size, and related to the eagitude of reinforcenent and the effost required for its production. At the primery neuronal level, impllence is depicted as involving normally occurring collateral inhibitory processes in afferent systems. The work of Dewson, liobel and Pribrar (1966) and Spinelli and Pribram (1966) is taken as direct evidence for the cxistence of these proposed systens.

To sumarize the Douglas-Pribram theory: It has been suggested that the hippocampus is a key structure in an error evaluating systea which mediates the effect of non-reinforced responses during learning. Organisms with hippocanpal distuption are rendered relatively insensitive to the effects of non-reinforcenent and are therefore required to learn appetitively motivated tasks via the remaining reinforcenent 
sensitive amyglaloid system. Although the theory is a posteriori in construction, Douglas and Pribran (1966) do present sone data confirming predictions made from the theory.

The present experiment focuses upon the hippocaipus and its proposed involvezent in situations involving non-reinforced responding. An experinental paradion in wich manipulation of reinforcement and non-reinforcement contingencies generates differential predictions concerning the behavior of hippocampectonized rats has been developed from the theory in question. In both the acquisition and reversal phases of a position discrimination, equation of the absolute number of reinforced responses to each of two to-be-discrininated eanipulanda combined with differentiation between the two in terms of the absolute number of non-reinforced responses would be predicted from the theory to retard both acquisition end reversel in hippocompectomized Ss when compared to neocortically-lesioned and sham operated controls. However, when the absolute number of non-reinforced responses to the manioulanda are equated and the number of reinforced responses differ, any hippocampal lesion-induced deficit would be predicted to be of a significantly lesser magnitude if present at all. Positive results would constitute support of the Douglas-Pribram theory (Douglas, personal commuication, 1968). 
MEIYOD

Subjects

The Ss vere 60 male Iong-Evans rats approximately 125 to 175 days old at the start of training.

\section{Apparatus}

A total of four experimental chambers vere enoloyed. One was constructed in the laboratory wile the reaining three were comercially obtained. The chamber constructed in the laboratory was a converted ice chest vith a sheetnetal partition diriding it into two coppartmenis. One conpertment contained a pellet dispenser and related reinforcenent delirery equiprent; the second comparteent, with the inclusion of a hardvare cloth floor, measured $28.5 \mathrm{~mm}$. by $28 \mathrm{~mm}$. by $23 \mathrm{~mm}$. high and served as the experiaental space. A Ralph Gerbrands Company rat lever was situated along the verticle center line of one vall, $2.25 \mathrm{~mm}$. above the hardware cloth floor. Reinforcenent was delivered to a food cup situated $5 \mathrm{~mm}$. above the manipulandus. An exhaust fan provided rentilation, and a 20 VDC bulb located in the center of the ceiling prorided lllumination during experinental sessions. The connercially obtained chambers were all Iehigh Valley Electronics Nodel 1316 small cubicles. $\triangle$ metal food cup was located along the verticle center line of one wall and rested on the grid floor. Two Lehigh Valley Electronics Model 1352 rat levers were mounted on the some wall, one on each side of the food cup. The center point of each manipulandum was $3 \mathrm{~mm}$. above the 
floor and $5 \mathrm{~cm}$. from the nearest side vall. Illumination was proviced by a 20 VDC bulb located $2 \mathrm{~mm}$. above the center of the plexiglass ceiling. All manipulanda were calibrated so that a weight of approximately 20 grams would activate the response circuitry. All experinental operations and contingencies were controlled by autoutic electro-mechanical programing equipment. Reinforcenent consisted of $45 \mathrm{mg}$. Noyes rat pellets. A plexiglass cover, measuring $3 \mathrm{~mm}$. by $7 \mathrm{~mm}$. by $14.5 \mathrm{ma}$. high, was available to cover either manipulandum in the two canipulanda chambers, thereby forcing $S$ s to respond on the uncorered nanipulandum when the conditions of training so required.

Experimental Desion

The 60 Ss were assigned in equal numbers to the 6 cells prescribed by the first two factors of a $3 \times 2 \times 2$ experimental design involving repeated measures as the third factor. Animals subjected to hippocampal, neocortical, or sham lesions (factor A) were assigned to conditions of differentiation training which insured that for each daily session either the number of reinforced responses or the number of nonreinforced responses (factor $B$ ) emitted on each of two manipulanda were equal, and were then tested in both the acquisition and reversal (factor c) of a two manipulanda differentiation.

\section{Procedure}

Upon recelpt from the supplier all Ss were placed on ad lib food and water. Following recovery from the rigors of shipment a mean base weight derived from five consecutive days weighing was established 
for each $\underline{\text {, and }}$ S vere reduced to $85 \%$ of these values and maintained at that level for the duration of pretraining.

The goal of the pretraining phase of the experiment vas to establish in each $\mathbf{S}$ a bar press response free of any procedurallyinduced left or right position preference. To accomplish this pretraining was conducted in the single manjpulandun chamber. Subjects vere first magazine trained and then shaped to press the manipulandum by the delivery of food reinforcenent. Spectal care was taken to insure that no S received a disproportionate amount of training under crî and 10: FR reinforcenent schedules. The reinforcenent ratio was grajually escalated and pretraining was terminated upon each S's demorstration of stable respozding under the requirements of an FR 10 reinforcenent schedule. Subjects were then returned to al lib food raintenance.

Following recovery of lost weight Ss assigned to the appropriate cells of the factorial design vere subjected to bilateral hippocailpal removal, bilateral removal of the neocortex orerlying the hippocampus, or bilateral sham operations in which the dura overlying the neocortex removed in the neocortical lesions was exposed. Following recorery from surgery a mean base weight derived from five consecutive days weighing was azain established for each $\underline{S}$, and $\underline{\text { S }}$ were reduced to $85 \%$ or these values and maintained at that level for the duration of the experiment.

Subjects were then returned to the single manipulandun chamber and retrained to respond under the conditions of the FR 10 relnforcement schedule. With fen exceptions reestablishment of control of responding by the FR 10 schedule was accoaplished during one session of approximately 
45 minutes duration. In no instance did this retraining require nore than three daily sessions. Followine completion of retraining in the single anipulandum chamber Ss vere advanced to the two canipulanda chambers in wich the experimental operations vere conducted.

During preliginary training in the two manipulanda chambers the right manipulandum vas first covered with the plexiglass cover provided for forced training. Responding on the lest ranipulendur was first maintained by a crif schedule of reinforcenent, and then by intermittent reinforcement. The reinforcement ratio was escalated one step followe ing every tenth reinforcement until 10 reinforcements on an FR 10 schedule were delivered. Subjects vere then removed from the chamber, the plexiglass cover zored to the left manipulandum, and the preliminary training regimen repeated. Those Ss which failed to eam $10 \mathrm{FR} 10$ reinforcements on either manipulandus within a 5-ginute period during which that schedule was in effect repeated the prelimirary training regimen the following day. With feu exceptions pretraining required no more than one session approximating one hour in duration; in no case vere more than 4 daily sessions required. On the day folloning the completion of preliminary training the experimental procedures vere initiated.

In discrimination acquisition responses on one manipulandum vere reinforced onan FR 5 schedule and responses on the second were reinforced on an FR 9 schedule. Of the 10 s in each of the two hippocampal and sham lesion groups, 6 vere assigned to one chamber and 4 to a second. Within each group the relationship between manipulandum and reinforcement schedule was counterbalanced. The two groups subjected to neocortical destruction were assigned to the third chamber and the relationship between manipulandum and reinforcement schedule al so counterbalanced. The first portion of each daily experinental session consisted 
of a 5-mirute free choice period during wich both manioulanda were exposed for responding and reinforced on the appropriate schedules. At the conclusion $0 \hat{i}$ the test period, which served to monitor the formation of the discriaination, the number of responses enitted and the number of reinforcepents earned on each manipulandum were recorded. The forced training portion to the exparimental session was then initiated. The purpose oi forced training differed for each of the two hippocampol, neocortical, and shem lesion groups. One each of the hippocenpal, neocortical, and shan lesion groups ves run under the condition prescribing the equation, for each $\underline{S}$, of the absolute number of reinforced responses enitted on each canipulandum during each daily session. The second hippocalpally, neocortically, and shan lesioned groups were run under the conditioning prescribing the equation, for each $\underline{S}$, of the absolute nuber of non-reinforced responses emitted on each manipulandum during each daily session. It should be noted that es a result of the utilization of an FR 5 and an FR 9 schedule of reinforcenent, Ss which emitted an equal number of reinforced responses on each manipulandur also eaitted twice as rany non-reinforced responses on the FR 9 manipulandum as on the FR 5 manipulandun. Conversely, Ss which enitted an equal number of non meinforced. responses on the two manipulanda also eaitted twice as many reinforced responses on the FR 5 manipulandur as on the FR 9 manipulandum.

Subjects assigned to the reinforced responses equated procedure fulfilled a dual requirement during each complete experimental session. These requircments vere: (a) each $\underline{S}$ eam an equal number of reinforcenents 
on the FR 5 and FR 9 manipulanda, and (b) a total of at least 50 reinforcenents be earned on each of the two manipulanda. If $\mathbf{S}$ did not earn the mininum 50 reinforcenents on either menipulandun during the 5-minute free choice period, the forced training portion of the session involved responding on both denipulanda. At the end of the free choice period the required number of make-up reinforcements to be earned on each manipulandun was determined, one manipulendun was covered, and $\mathbf{S}$ was allowed to respond on the second until the required nuriber of make up reinforcements for that manipulandum had bees delivered. The cover was then moved to the second manipulandum and S was allowed to respond on the first until the requirements for that Eanipulandur had been fulfilled. For examle, if $\mathrm{S}$ earied 40 FR 5 reinforcenents and 25 FR 9 reinforcenents during the free choice period, S would be required to earn an additional 10 IR 5 reinforcem ments and 25 FR 9 reinforcements during the forced training period. As a result, $\underline{5}$ vould have earned an equal nuber of reinforcements (50) on each manipulandum during the course of the experimental session. The order in which the manipulanda vere covered alternated across daily sessions.

If $\underline{S}$ earned 50 or core reinforcements on either, or both manipulanda during the free choice period, the forced training period involved responding only one manipulandum. At the terinination of the free choice period the difference between the number of reinforcements eamed on the two manipulanda was determined, and the manipulandum on which $\underline{S}$ had earned the greater number of reinforcenents vas covered. The S was then allowed to respond on the second maripulandun until the 
requirea number of malre-up reinforcements vas delivered. For example, if $\mathrm{S}$ earied $65 \mathrm{FR} 5$ reinforcenents and $20 \mathrm{FR} 9$ reinforcenents during the free choice period, the ER $S$ canipulendun vould be coverei during the forced training period and $\underline{S}$ rould be allowed to respond on the $F R$ 9 manipulardu until 45 reinforcenents had been delivered. This fulo filled the requirement that $\underline{S}$ emit an equal number of reinforced responses, in this instarce 65, on each catipulandun during cach experiDental session.

Subjects assigned to the noumeinforced responses equated procedure fulfilled a different dual reguirement curing each experimental session. These requireants were: (a) each S carn tuice as many reinforcerents on the ER 5 canipulandu a.S on the $R$ R 9 aanipulandura, and (b) a cinicui of 60 reinforcenents be earned. on the FR 5 manipulandum and, consequently, a minimun of 30 reinforcerents be earned on the FR 9 manipulandum. The free choice period and subsequent forced training procecded in a canner analogous to that described above for the $\mathbf{S}$ assigned to the reinforced responses equated regiden. In the present condition, î S failed to carn the minimur 60 and 30 reinforcenents on both the FR 5 and F⿱ 9 manipulanda, respectively, during the free choice period, the forced training pericl vould insure that these minina vere earned. For example, if $\underline{\mathrm{S}}$ earned $40 \mathrm{FR} 5$ reinforcenents and $25 \mathrm{FR} 9$ reinforcenents during the free choice pericd, he would be required to earn an additional $20 \mathrm{FR} 5$ reinforcements and $5 \mathrm{FR} 9$ reinforcements during the forcel training period. The $\underline{S}$ would have therefore earned the mininum 60 and 30 reiniorcements on the FR 5 and FR 9 ranipulanda during the course of the experimental session. 
If $\underline{S}$ earned core than 60 reiniorcements on the FR 5 canipulandu and/or wore than 30 reinforcenents on the FR 9 manipulandur during the free choice period, the forced training period intolved only one manipulandum and served to insure that the ratio of reinforcements carned of the FR 5 manipulandur to those eamed on the FR 9 manipulandus vas 2 to 1. For examle, if $S$ earned $70 \mathrm{FR} 5$ reinforcoments and $40 \mathrm{FR} 9$ reinforcements during the free choice period, S vas required to carn an additionol 10 FR 5 reinforcements during the forced training period. As a result, S earned a total of $80 \mathrm{FR} 5$ reinforcenents and $40 \mathrm{FR} 9$ reinforcewents during the course of the experimental session, and fulfilled the requirerent that the ratio of FR 5 to FR 9 reinforcenents be 2 to 1. If $\underline{S}$ earmed $90 \mathrm{FR} 5$ reinforcements and $10 \mathrm{FR} 9$ reinforccments during the free choice period, S was required to earn an additional 35 FR 9 reinforcenents during the forced training period. The $\underline{S}$ therefore earned a total of 90 FR 5 reinforcenents and 45 FR 9 relniorcenents, and the ratio of FR 5 to IR 9 reinforcenents vas again the required 2 to 1 .

Discrinination training was terminated when S attained a criterion of at least 90\% responding on the FR 5 annipulandum in 9 of 10 consecutive free choice periods. Upon coinletion of this requirement S was subjected to one half again as many daily sessions as vere required for attainzent of the criterion and then goved to the discriaination reversal phase of the experiment. If it became statistically impossible for $S$ to satisiy the criterion within 40 days of trafning $\mathbf{S}$ was considered to have failed to satisfy the requirenents for discrinination and was then nored to the discrinination reversal phase of the study. 
Discrinination reversal training uas instituted for each $\mathbf{S}$ on the day following teraination of the acquisition portion of the expericent. In reversal training the relationship between reinforcew Eent schetule and ranipulandur vas reversed for eacil S. Training in revcrsal procceded in the sace fashion for the two groups as described in the acguisition phose above. Reversel training was teruinated when each $\mathbf{S}$ cet either the criterion of acquisition or failure established for the acquisition phase of the study.

\section{Surcary}

All Ss vere operated under $40 \mathrm{Hg} / \mathrm{iz}$ Membutal anesthesia supplemented with $.30 \mathrm{cc}$ of atropine injected interperitoneally. 111 operations were feriorued while $\mathbf{S}$ was held in a Baltimore stereotexic instrument. A dissecting scope vas employed to assist in the visual guiding of neocortical and hippocenpal removal. In all operations the shull was exposed by gans ô a midine incision, bilateral trephine holes were placed lateral to the nidline and posterior to bregna. The holes were enlarged with rougures to expose the neocorter overlying the dorsal and lateral portions of the hippocampus. In the sham operated Ss surgery was terzinatel at this point. For those Ss sustaining neocortical removal the dural was cut and the neocortex orerlying the hippocarpus vas aspirated off, with care tairen not to damage the hippocanpus. For those Ss sibjected to hippocanpectoriy the operation proceeded until the thalamus was exposed. In addition, hippocampal removal was expended. anteriorally as far as the hippocomol comiscure as vell as extended around the posterio-lateral surface of the thalamus. Care vas taken not 
to eamage the fralanus. Folloning completion of surgesy Ss vere returned to thezis hone cages and waintained on a vater and tetracycline solution for teree to five days.

\section{Histology}

Followitg the terminaticn of the experinent ail Ss were sacrificel with a lethal dose of Nembutal anesthesia and intracardially perfosed vith saline followeu by a 10\% formlin solution. All brains vere then remored froa the brain cerities and those of the SS in the neocortical and hippocangal eroups were infiltrated with, and enbedded in, celloidin and sectioned at $15 \mathrm{u}$. Frery terth section was retained, nounted on a silde and stained with thionin. In addition, for 5 Ss in each lesion sroup the section following the thionin section was stalued with wise and then mounted. 


\section{RLSUIIS}

Tracinss of representative cross sections through the hippo canpal and neocortical lesicus are presented in Figures 1 and 2, respectively. Hippocanpal Cestruction regilarly involved at leasi 75, of that structure and in ali instances resulted in the complete separation of the dorsal ant lateral aspects of the hippocampal formation. Specific damage to the thalamus was mininal and, when erident, was typically unilateral in nature. The neocortical lesions did not encompass a rolume of tissue comprable to that rezored in the hippocappl lesions, but did approximate the noocortical destruction incurred by the hippocarectomies. Fippocanpel damage resulting from the neocortical lesions was minima and, if present, usually unilateral in nature. Gross exanination of the intact breins of those Ss subjected to shas operations retealed no disceruible neocortical damage.

The sessions requires to attain criterion in acquisition and reversal by those sham, neocortically, and hippocampally lesioned Ss trained under the reinforced responses equated resicen are presented in Table 1. The trials to criterion for Ss assigned to the non-reinforced responses equated condition are presented in Table 2. Inspection of these tables sugzests there is an injerse relationship between performance in acquisition and reversal. It appears that $\underline{S}$ who readily attain criterion in acquisition are retarded in reversal and, to a lesser degree, Ss who are retarde in ecquisition appear to perform vell in reversal. To test the possiblilty of sucis en interse relationship, all Ss were ranked 

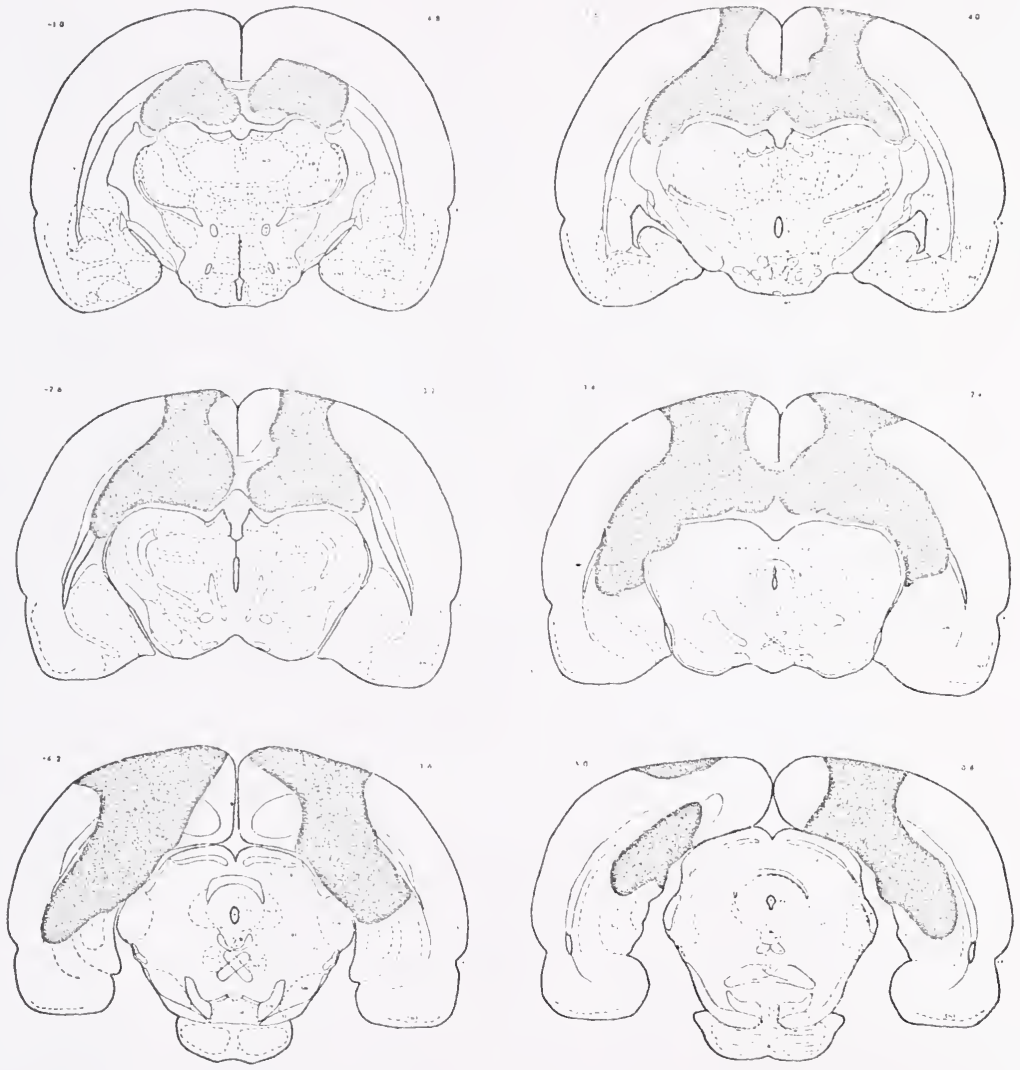

Fips 1. $\rightarrow$ Tracings of representative cross sections through the
hippocampal lesion (After Pellegrino and Cushman, 1967). 


\section{TABLE 1}

TRIAIS TO CRIPERTON IN ACQUISITIOI ATD REVERSAT, FOR SHA, HEOCORICALY, AND HIPPOCA.PPALLY ITSIONTD SS ASSIGIED TO THE RHITFORCED

\section{RESPOISES EQUTATED CONDIIION}

\section{Acquisition}

Reversal

Shan Control

Neocortical Lesion

Hippocaypal Lesion

11 


\section{TABLE 2}

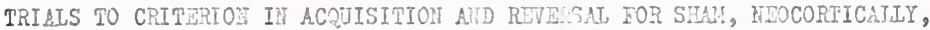
AID HIPPOCATPATIY I ISIONDD SS ASSIGTED TO THE NOIREITAORCEI RESEOISES EQUATED COMDITION

Sharn Control

21

10

15

13

9

10

9

10

18

11

Neocortical Iesion

Hippocempal Lesion
10

11

40

13

12

10

10

10

31

9

11

11

19

16

10

9

9

10

10

10
12

32

13

16 24

40

22

32

16

22

17

19

15

13

12

15

20

16

14

13

14

25

14

14

12

17

40

17

14

12 
from 10t to high on the number of sessions to attain criterion in acquisition, and from high to $10 \mathrm{~s}$ on the number of sessions required to attain criterion in reversal. A Spearcan rank oraer correlation coefficient $\left(r_{\mathrm{S}}\right)$ was then computed (Siegel, 1956), and found to be significant $\left(r_{S}=.47, t=4.0567, d f=59, p<.001\right)$. Spearian rank order correlation coeficients were also computed in the same manner for the sher, neocorifal, and hippocampal lesion Eroups (see Table 3), and for the three lesion groups when forthor divided on the basis of the reinforced versus non-reinforced responses equated dinension (see Table 4). The forner analysis indicates the inverse ralationship between perfortance in acquisition and reversal is present in only the shad control Ss; the latter analysis reveals that while the sham control $\underline{S}$ under the non-reinforced responses equated condition do shos this relationship, their counterparts under the reinforced responses equated condition do not. In addition, the finer grain analysis indicates that the hippocampectonized Ss under the reinforced responses equated condition also danifest this relationship, albeit to a lesser degree.

The sessions required to attain criterion in acquisition and reversal for sham, neocortically, and hippocampally lesioned Ss under the reinforced responses equated requirenent are presented sraphically. in Figures 3 and 4, respectively. Analogous data for $\underline{S}$ under the non-reinforced responses equated condition are presented in Figures 5 and 6. An analysis of variance assessing the effects of the three lesion conditions, the two response-reinforcement contingencies, and acquisition and reversal upon performance as indezed by the trials to criterion measure was performed (Hiner, 1962). Since the trials to criterion 
TABIE 3

SPEARINY RATK ORDER CORRETA'ION COFEICIENTS $\left(r_{s}\right)$ FOR SHA', NEOCORTICAI, ATD HIPPOCANPAI IESIOH GROUPS"

Shan Control

$$
\begin{aligned}
& r_{s}=.51 \\
& p<.05
\end{aligned}
$$

Neocortical Lesion

$$
r_{s}=.10
$$$$
p>.05
$$

Eippocarpal Jesion

$$
\begin{aligned}
& r_{s}=.36 \\
& p>.05
\end{aligned}
$$

*See text for raniing procedure. 
TABIS 4

SPEARIAN RAIK ORDER CORRTLATION COETICTITTS $\left(r_{S}\right)$ FOR SHAH, NEOCORTICAL, AND HIPPOCNIPAL LESION GROUPS UIDDR EOURTED RETNSORCED

OR NONORENFORCAD RTSPONDING DURING TRAINIMG:

Reinforced Responses

Enzuated

Sham Control

$\begin{array}{ll}r_{S}=.42 & r_{s}=.76 \\ p>.05 & p<.01\end{array}$

Neocortical Iesion

$r_{\mathrm{s}}=.06$

$r_{s}=.29$

$p=05$

$p>.05$

Hippocamal Lesion

$$
\begin{aligned}
& r_{s}=.68 \\
& p<.05
\end{aligned}
$$$$
\mathrm{r}_{\mathrm{S}}=.35
$$$$
\mathrm{p}>.05
$$

* See text for ranking procedure. 


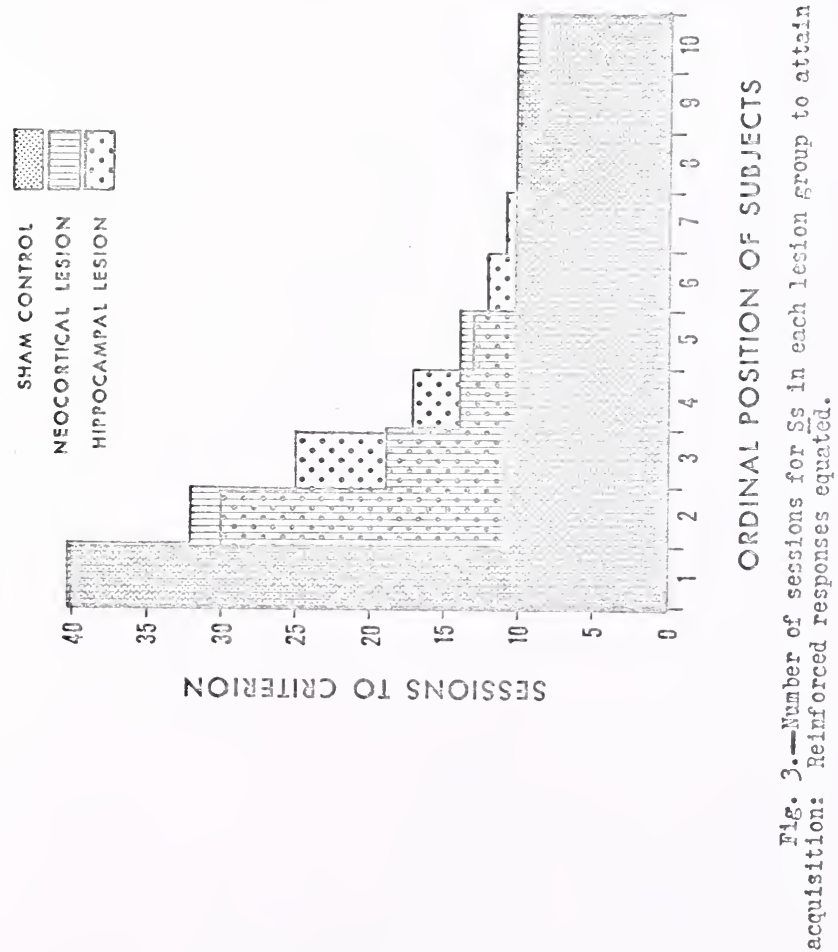

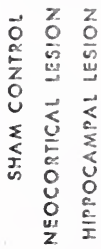




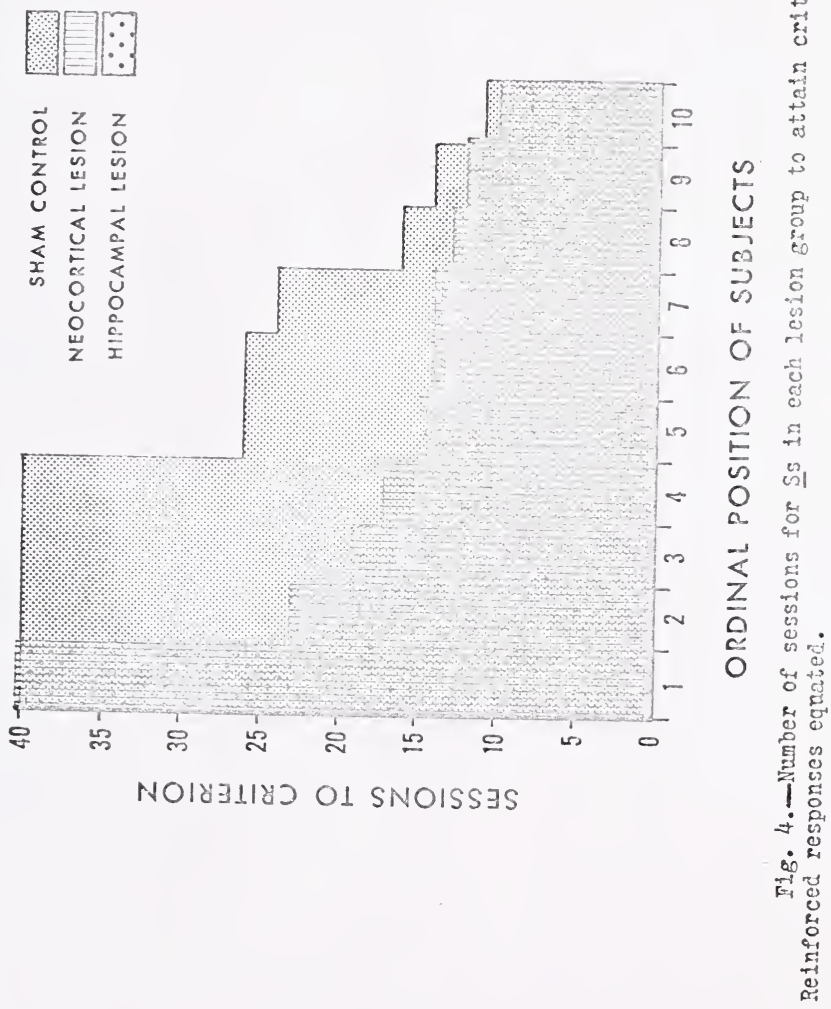




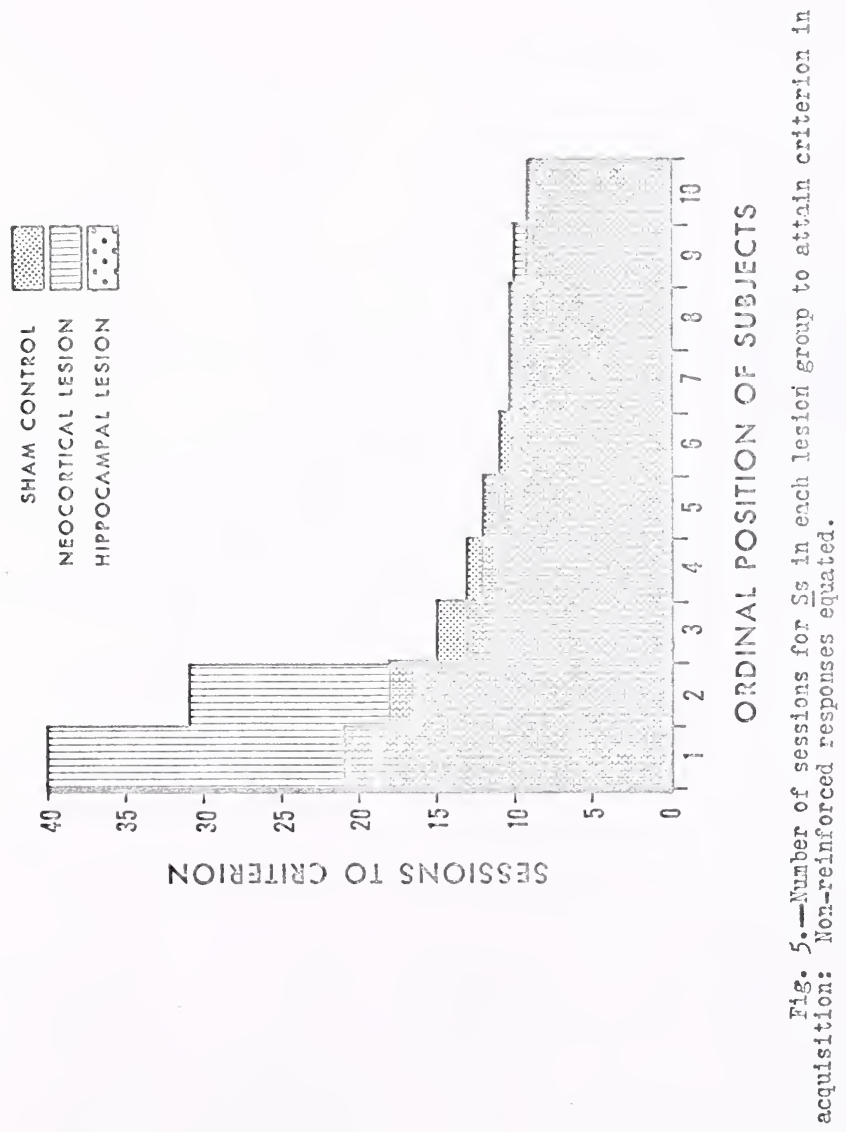




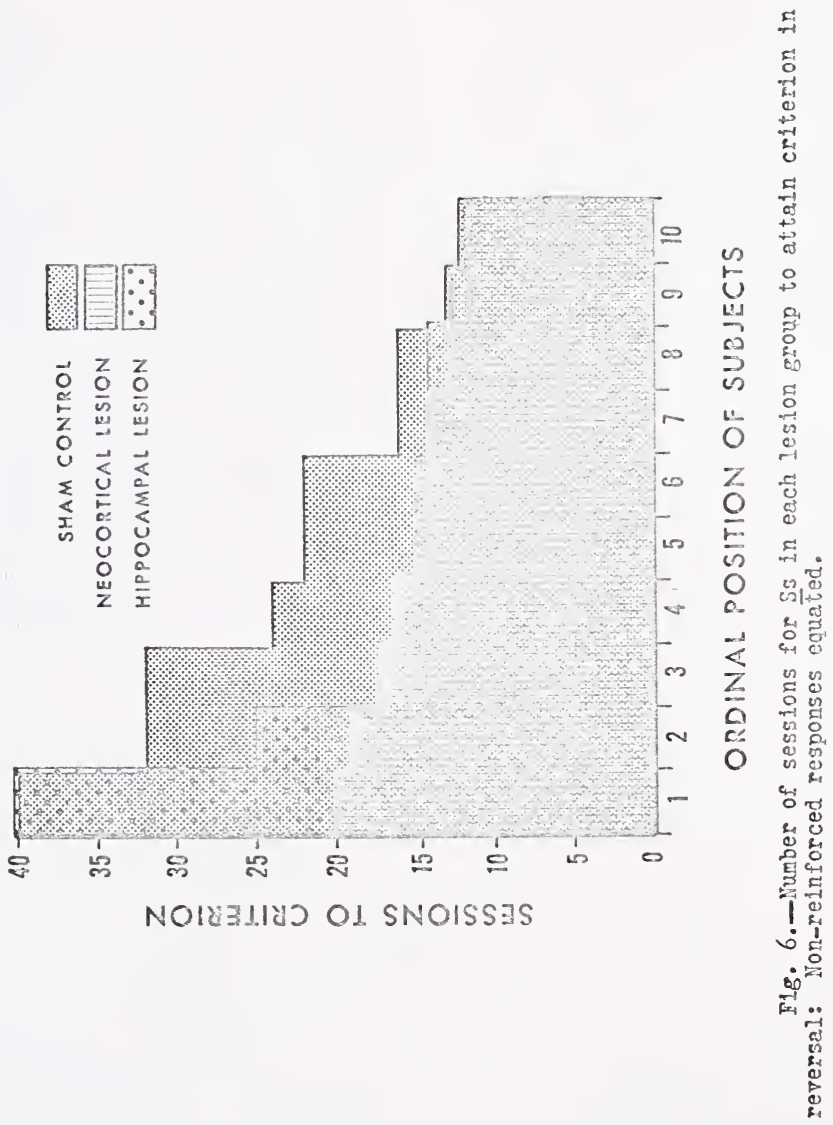


reasure produced slightly skend data, these ralues vere subjected to a square-root transformation and a second analysis of variance perforaed upon the resultant date. The results of these tro analyses are presented in sumary fashion, in Tables 5 and 6, respectively. A comparison of the two tables reveals little inconsistency in the results of the two analyses.

An exanination of Figure ?, which depicts the cumulative percentage of $\underline{S}$ in each lesion group attrining criterion in successive five session blocis, susgests that the neocortically and hippocarpaily lesioned Ss are sligitly facilitated with respect to the sham control Ss in discribination performance. The anelyses of variance indicate that this difference is not large enowing to be statistically reliable. Hoverer, the results of the analyses do reveal a significant interaction between this factor and the acquisition and reversal phases of training wilch Eust be exanined berore it can be concluded that the various lesion conditions have no effect on discrimination learning.

1 comparison of the effects of equating either reinforced or nonreinforced responses during discrinination training is depicted in Figure 8. Heither level ô this factor, nor this factor's interaction with the lesion dimension, were indicated by the andyses of variance as differentially affecting perfornance in the discrimination task.

Inspection of Figure 9, which represents performance in the acquisition and reversal phases of the study, suggests that $\mathrm{S}$ attained criterion more rapidy in acquisition training than in reversal training, and this is verified as a significant difierence by the analyses of variance. 
TABTE 5

ANATYSIS OF VARIANCE ON MRIALS TO CRITERI ON

\begin{tabular}{|c|c|c|c|}
\hline Source & NS & $d \hat{q}$ & $\mathrm{~F}$ \\
\hline Between Ss & & 59 & \\
\hline Lesions (A) & 117.11 & 2 & 2.23 \\
\hline Resyonsemeinforcement Contingency (B) & 151.89 & 1 & 2.90 \\
\hline$A \times B$ & 2.79 & 2 & 0.05 \\
\hline Ss Within Groups (Error) & 52.46 & 54 & \\
\hline Within Ss & & 60 & \\
\hline Acquisition-Reversal (C) & 795.69 & 1 & $7.93 \% *$ \\
\hline$A \times C$ & 417.62 & 2 & $4.16 *$ \\
\hline$B \times C$ & 1.86 & 1 & 0.02 \\
\hline$A \approx B=C$ & 83.21 & 2 & 0.83 \\
\hline Cx Ss Within Groups (Exror) & 100.35 & 54 & \\
\hline
\end{tabular}

$* p<.05$

**p $<.01$ 


\section{TABLE 6}

ANALYSIS OR VARTANCE ON SOUARP-ROOT TRANSFOPIATIOAI OF TRIATS TO CRITERION

Source

VS

df

I

Between SS

59

Lesions (A)

1.23

2

1.7

Response-Reinforcenent Contingency (B)

1.38

1

1.91

$A \times B$

0.02

2

0.03

Ss With Groups (Error)

0.72

54

Within SS

60

LcquisitionaReversal (C)

10.96

1

$6.61 \%$

$A \times C$

5.42

2

$3.27 \%$

$B \times C$

2.01

1

1.21

$A \times B \times C$

0.04

$2 \quad 0.02$

C $x$ Ss Within Groups (ESTOs)

1.66

54

$$
* p<.05
$$




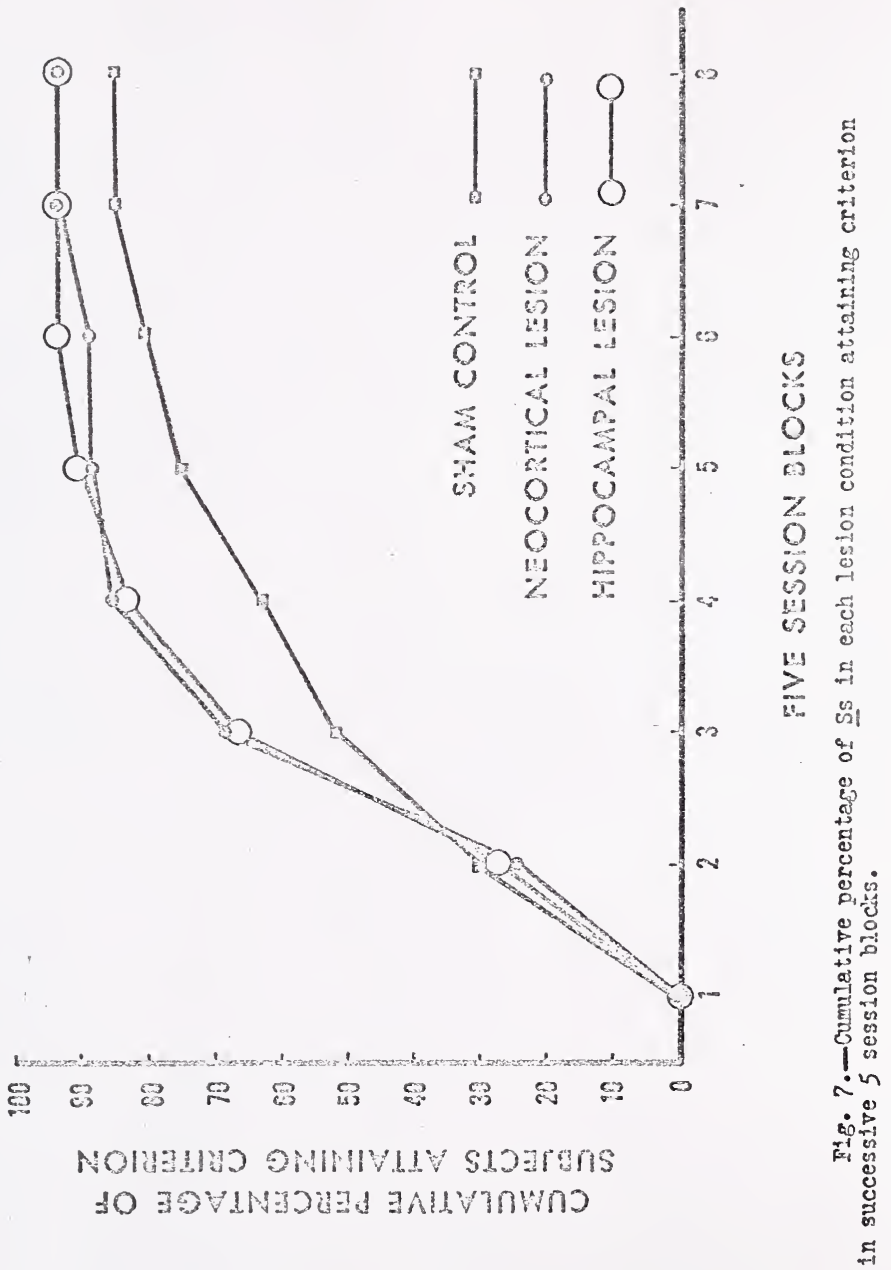




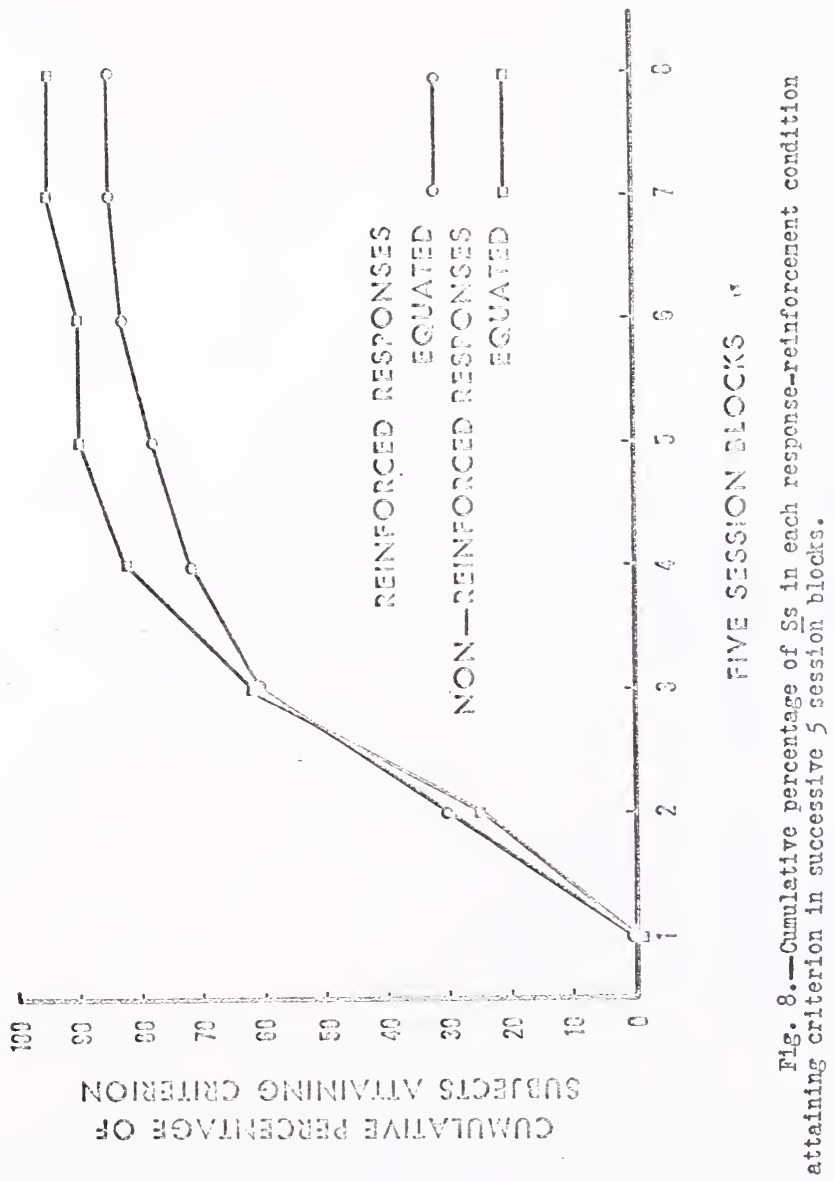




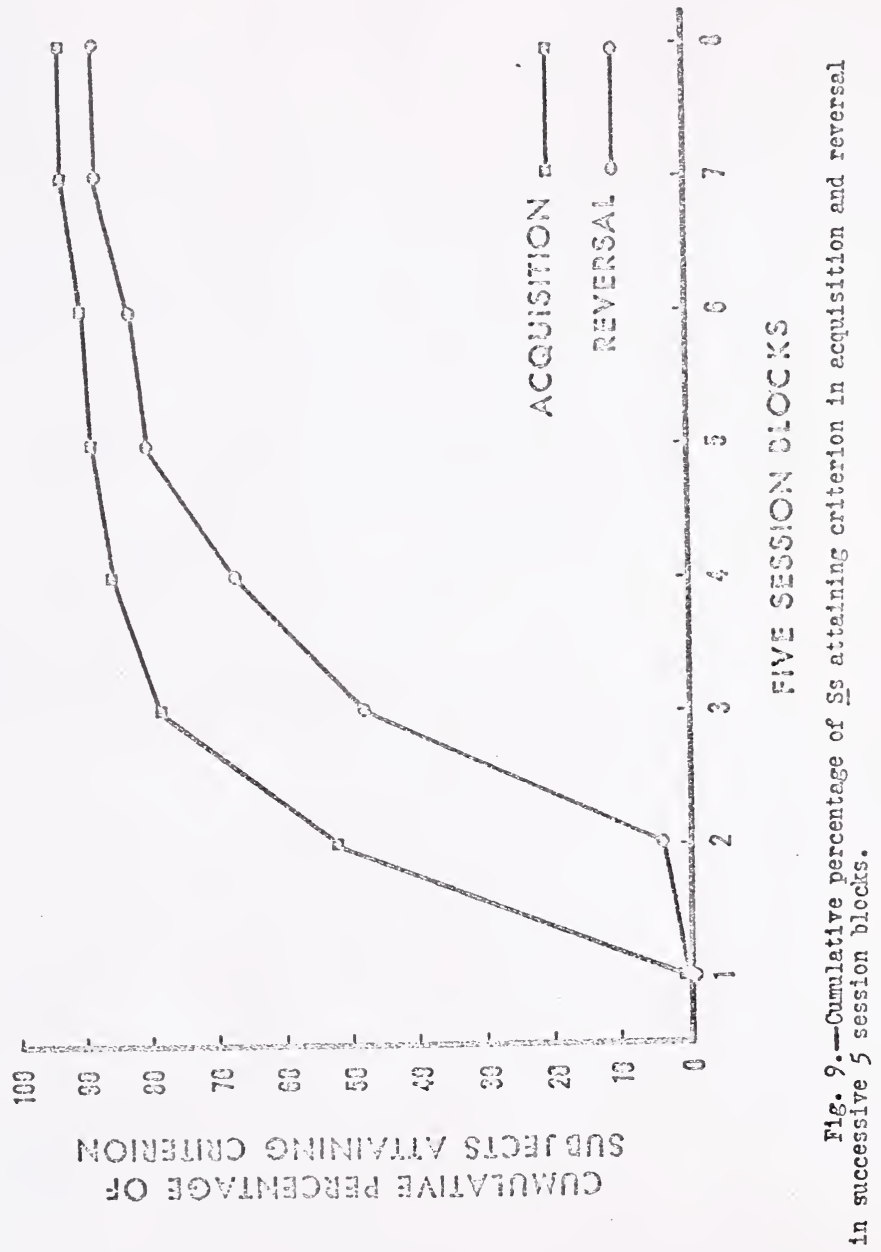


As indicatcd previousiy, a signiricant interection between the lesions factor and the acquisition and reversal phases of training vas revealed by the analyses of variance. The components of the inter. action are depicted in Fiore 10, winch presents the periormance of the three lesion groups in acquisition training, and in Figure 11, which presents theil perforance in reversal training. The nean trials to criterion for Ss in each of the three lesion fioups is presented. for acquisition and reversal in Figure 12. Fxamination of these figures sugzests thot the three lesion groups did not differ in the acquisition phase of training, but that in the reversal phase tho neocortically and hipocanzlly lesioned Ss, while not differing anong theaselves, did attain the criterion wore rapidy and in grater nubers than the shem control Ss. A posteriori comprisons betreen the cell vears involved in this interaction were periomed utilizing the Studentized range statistic (IIner, 1962). The results of the comparim sons are piesented, in surmary fashion, in Table 7. The results support the above observations and reveal, in addition, that shan control Ss attained criterion significantly faster in acquisition than in reversal, but that such a difierence is not present in the reocortically and hippocampally lesioned Ss. Neither the remaining first order interaction (lesions by response-reinforcenent contingency) nor the single second order interaction (lesions by response-reinforcenent contingency by acquisitionmreversal) attained significance. 


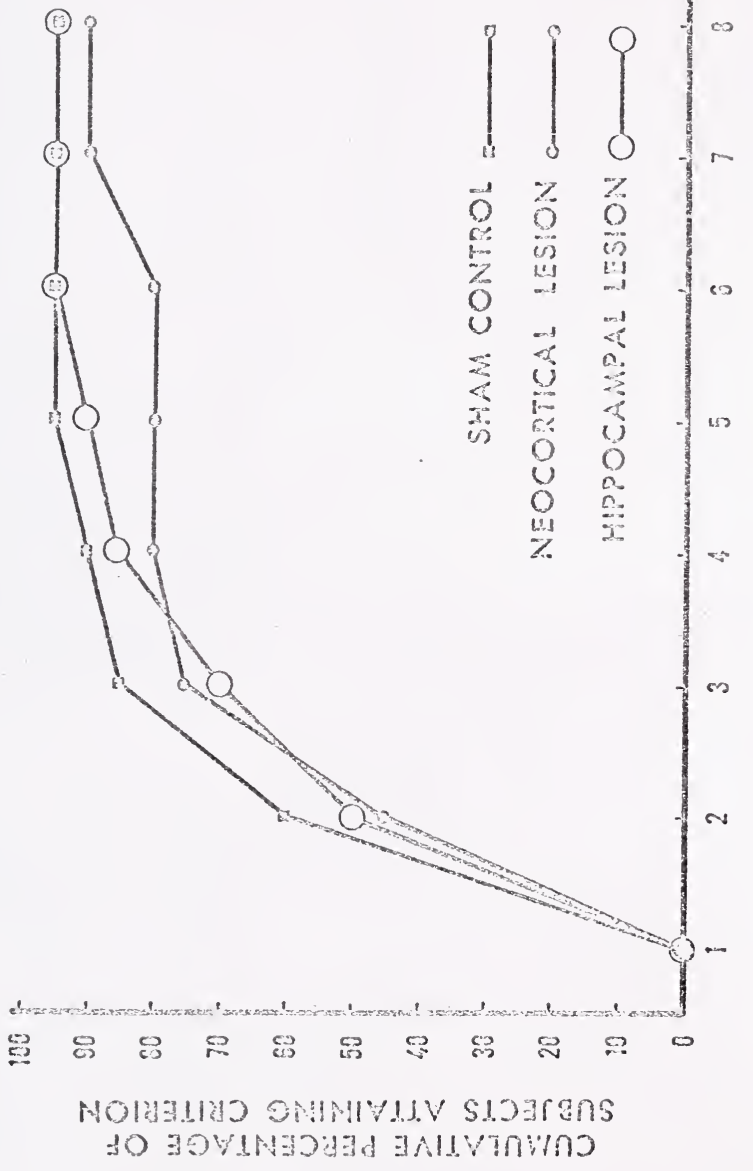




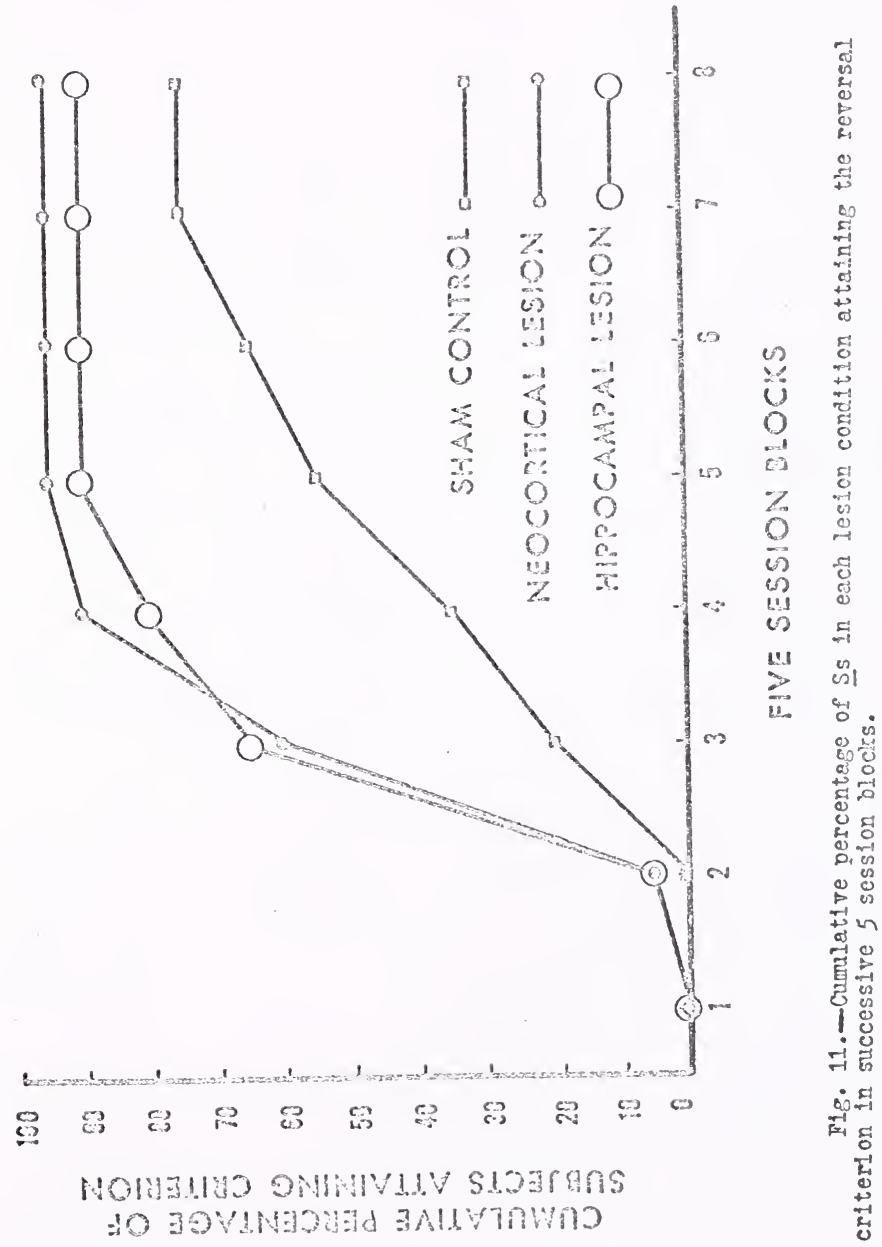



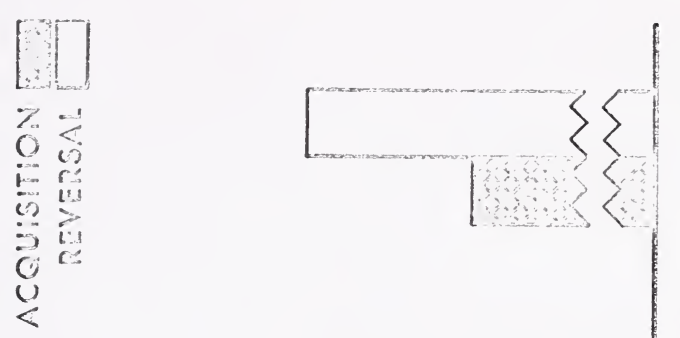

$\ldots$

$\Leftrightarrow \rightarrow$

$\sum \forall$ il

(i) 12 क

(i) $1: 3$

a

$\therefore$

1

()

i) 0 :

o is is

() 1.5 th

( ). 캐

I.)

$\%$

s
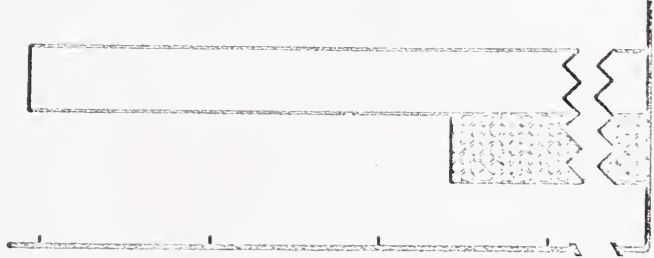

$\sum 0$ 岁

$\leqslant \%$

(i) 0 :

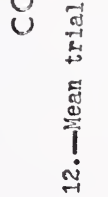

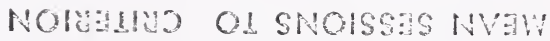


TABLE?

STUDENIZED RAIGP STARISTIC A POSTRRIORI TESTS

Acquisition

Shan VS. Neocortical Lesion

Shan VS. Hippocarpal Lesion

0.86

Neocortical TS. Hippocenpal Iesion

0.83

Reversal.

Shar VS. Neocorticel Lesion

$20.29 \%$

Sham VS. Hippoconpal Lesion

Jeocorical ve Hippocenpal Lesion

Sham Control

Lcquisition rs. Retersal

Neocortical Lesion

Acquisition Vs. Reversal

0.01

Hippocanoal Lesion

Acquisition VS. Reversal

$\because p<.01$ 


\section{DISCUSSIOIT}

This study exanined the performance of sham, neocortically, and hippocanpally lesioned rats in the accuisition and reversal of a tho manipulanda differentsation as afiected by certain vanipulations of responsemeinforcenent contingencies. For onemalf the shat, neow cortically, and hippocampally lesioned Ss, these canipulations insured that each S exitted an equal number oi reinforced responses on the two dianipulanda during a complete experinental session. As a result of this procedure, each $\underline{S}$ also ezitted tyice as many non-reinforced responses on one canipulandum (the FR 9 genigulandum) as on the second (the FR 5 manipulandum). For the ramining $S$, the experimental manipulations insured that eaci $\mathbf{S}$ enitted an equal nuber of nonreinforced responses on the tro manipulanda during a complete experim mental session. As a result of this procedure, each S eaitted twice as many reinforced responses on the FR 5 nenipulandum as on the FR 9 manipulandum.

The Douglas-Pribrag theory of hippocanpal function (Douglas \& Pribran, 1966; Douglas, 1967) is a vigorous attompt to integrate the wide variety of behavioral changes following hippocaspal dismunton, and leads to clear-cut predictions of the behavioral effects of the manipulations performed in this study. Specifically, the theory predicts retarded acquisition and reversal in hippocanpal Ss when compared to shan and neocortical control Ss under the treatment condition whici specifies equation of the number of reinforced responses enitted 
on the tro manipulande, less or no retardation in hippocanpal SS under the condition which served to equate the number of non-reinforced responses emitted on the discriminanda, and, indirectly, no difference betreen shan and neocortical Ss under either of these two treatrient conditions. These predictions are contradicted by the results of this expericuent.

The trials to criterion data do not reveal any differences between the three lesion groups in acquisition performance. This finding is in general accord with the results of recent studies of the role of the hippocanpus in discrinination learning. However, such studies have not examined the epfect of dif̂erential densities of reinforced and non-reinforced responding to the alternative discrininanda upon discrinination learning in hippocempectomized Ss. The present findings, although inconsistent with predictions derived from the Douglasmpibran nodel, indicate that such differences have no significant effect on acquisition performance in either sham, neocortically, and hippocampally lesioned Ss.

The perfornance of the three lesion groups in reversal also is inconsistent with predictions derived fron the Dovglas-Pribran for, as in acquisition, the two response-reinforcement contingencies do not differentially affect in either sham, neocortically, or hippocampally lesioned $\mathbf{S}$. In addition, the reversal data appear to be inconsistent with the bulk of the data on the performance of hippocanpectomized and control Ss in discrimination reversal; namely the hippocampally lesioned Ss are typically reported as retarded in discriaination reversal when compared to neocortically lesioned and shan control Ss tho usually 
do rot differ fron each other. The results of the present study indicate that it is neocortically and. hippocampally lesioned Ss who do not differ from each other, and both appear facilitate when conpared to sham opcrated $S$ on the trials required to attain criterion in roversal. A cosparison of the sessions to criterion data with alternative per. formance reasures, such as trials to successive criteria and the absolute per cent of FR 5 responding for successive days, revealed that 2II three nessures depicted acquisition and reversal perfornence in a sinilar fasilion.

A poseible explanation of this disparity is offered by the relationship Estreen acquisition and reversal persomence as revealed by the Spearian rant order correlation coeficicient. The sham operated Ss, who require a significantly greater nuber of trinls to attain criterion in reversel when compared to the reocortically and hippocampally lesiozed Ss as indicated by the studentized range statistic, are also the Is wh nanifest a significant inverse relationship between trials to criterion in acousition and reversal. In addition, a greater number of $S \mathrm{~S}$ IT the shan control group attained the criteirion in 11 or less sessions ( 15 of 20 ss) than in either the neocortical (11 of 20 Ss) or hippocampal (12 of 20 S) lesion groups. When the threc lesion groups are parstioned in teras of the response-reinforcement contingencies, similar phenomena are observed. These findings suggest that some Ss possess an initial position preference which, when in accord with the requirements of the initial differentiation, facilitates acauisition ans retards reversal. Horeover, it appears that a greater proportion of $\$ 3$ in the shen operated group fall into this category 
than in either of the two other lesion eroups. It nay be assured, then, that the poorer performance of the sham control $\underline{S}$ in reversal is an artifact resulting from a follure to completely control for initial position preference, and that if this had boen done the differences between the three lesion groups in reversal would be elininated.

The experimental procelures enployed in this study differ in a number of details fros those in which hippocamel lesion-induced dericits in discrimination reversal are comonly observed. It is possible that the lack of a lesion-inducad deficit in the present study may be attributable to one or gore of these differcnces. One such nodification involves the utilization of an overtraining procedure foljoming attaingent of criterion in acquisition. Investigations of the effect overtraining voon reversal in the $T=$ maze indicate that $\mathrm{S}$ s subjected to, on the average, at least 1.3 (Hacintosh, 1962) and 3 (Pubios, 1956) tines as many overtraining trials as vere required to reach criterion in the acquisition of a discrimination perford better in reversal than Ss vithout overtraining (the overtraining reversal effect). An exanination of Reid's (1953) data indicates that when overtraining involves less trials than were required to attain criterion the overtraining reversal effect is not seen. It is difîicult to compare those procedures and the present one, for different responses and procedures were employed. Hovever, since this study employed only one-half as rary overtraining sessions as were required to attain the acquisition criterion it is unlikely that the overtraining reversul effect was operative. Despite this, an exanination of the overtraining reversal phenonenon does add to an understanding of the results of this study.

Macintosh (1965) notes that it is presumably justifiable to regarẻ reversal leaming as consisting of two parts:

(a) extinction 
of a tendency to select the former $S^{D}$, and (b) accuisition of a tendency to select the nev $S^{D}$. Stage (a), extinction, is usually regarded as continuing so long as S scores belou chance level, and stage (b), acquisition, is typically depicted as comencing as soon as S begins to periory abore chance level. It should be noted that itplicit in the fornulation described by hacintosh is the generally accepted assumption that learning is a contimuous, rather than oiscontinuous, process. Whether this is indecd the case has not yet been completely resolver. The present discussion is concermed primarily with the effect of attentional factors upon discrimination reversel rather than with the underlying nature of the learning process.

It is often reported that orertraining of a Iunvy response results in reduced resistance to extinction (Vener, 1963). It is logical to assurite, therefore, that this phenomenon is what underlies the overtraining reversal effect; nanely, overtraining facilitates extinction of responses to the forner $S^{D}$ in the formulation described by llacintosh. This is not the case, hovever, for overtraining in the discrimination faradign regularly increases resistance to extinction of responses to the former $S^{D}$ (Kacintosh, 1962). As Nacintosh (1965) points out, overtraining facilitates reversal of a simultaneous discrimination not because of, but in spite of its effect on extinction. This finding would appear to negate an extension of the frustration (Lawrence \& Festinger, 1962) and generalization decrenent (Kimble, 1961) explanations of extinction to the overtraining reversal effect and, by implication, to reversal training in general. 
lacintosh (1965) reports that existent evidence indicates overtraining facilitates reversal by shortening runs of incorrect responses during the middle of the reversal. This suggests that overtraining reduces $\underline{S}$ ' tendencies to respond to irrelevant cues during reversal. There are two possible explenations for this: Either overtreining effectively crables Ss to "adapt out" cues along irrelevant dinensions; or overtraining allows arple opportunity for Ss to learn to attenc to the relerart cue dimension. Macintosh presents evidence which indicates that it is the latter alternative which underlies the overtrainine reversal effect, and points out a distinction between research utilizing visual and spatial cues. Studies wich have in. rolred a simultoneous visual discrinination (bijontness, fattern, etco) invariably produce the orertraining reversal efrect, while those studies which enploy a spotial discrinination (left turn versus right turn in $\mathrm{T}$ and Yamazes, etc.) frequentiy do not. A major reason for this, Hacintosh contends, is that the rat (the conmonly used experjmental organisa) is primarily spatially oriented and, as a consequence, spatial cues have a high priority even without overtraining. Since the rat is alreedy attending nainly to spatial or position cues, overtraining would not be expected to have wuch effect on performance in reversal. Conversely, the lower the relevant cue dimension is on the Ss "attending hierarchy," the more valuable overtraining vould be expected to be in firmly establishing the relevant cues in a position of dominance. The dagnitude of the overtraining reversal effect should be inversely related to the probability that $\mathrm{S}_{\mathrm{S}}$ ill attend to the relevant cue at the beginning of discrimination training, and to the number of irrelevant cues involved in the discrimination. 
The preceding discussion is rextedly similar to the Douglas. Pribran conceptualization of the role of the anygdale in discrimination learning; numely, the registration of the effects of reinforcement or, alternatively. the direction of attention to the aspects of the tasi (relevant cues) associated with reinforcement. Hovever, the above formation of the function of attentional factors in discrimination learming does not incorporate a process analogous to that attributed to the hippocarpus; the gatirg out of stinuli associatcd with non-reinforce. nient. It vili be recalled that an alternative to the attentional rodel indicates that the orertraining reversal efiect can be attributed to the opportumity for SS to effectively "adapt out" irreievant cues (Spence, descrazbed in Nacirtosh, 1965). Perinaps an explanation of the overtraining reversal eifect involves both these processs. The Douglasmpribrar model suggasts that this is so. In adidion, the results of this study Lay not be as inconsistent with the DoublasPribram nodel as vas first indicated. The difrerentiation required in the present strdy involves spatial cres, a dirension thought to be high on the rat's "attentional bierarchy." If this is the case, the role of the hippocarprss, that of gating out irrelevant sticuli, would be

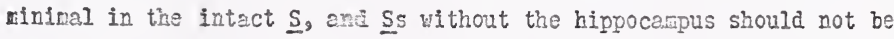
greatly 1ncired. Perhaps a hippocampal lesion-induced deficit would be evident in the present Earadig if a task inrolving a non-spatia. differentiation, or, nore Erobably, a differentiation between a large number of equaly salient cues bas employed. Support for this possin bility is proviled by Pribres (1969), who reports that hippocanpectonized monteys shou revardation in discrinination learning, provided there ere 
a large number of non-revarded alternatives in the situation (pg. 137).

A second procedural innovation employed in the present study involves the response selected for study. Those studies, reported previously, which have demonsirated the hippocamnal lesion reversal dericit have typically employed an instrumental response requiring soze form of gross loconotion on the part of $\mathbf{S}$. In contrast, this study utilized an operant response, a bar press, wicl, unlike the typical instmanental response, requires a minimum of locomotion, takes a short tine to execute, requires relatively little eîrort, and leaves $\mathrm{S}$ in the same place ready to respond again. Although it is generally aswined that the behaviofal principles and neurophysiological wechanisas underlying what appear to be analogous tasks in the two experinentel approaches do not differ in any critical aspect, a thorough coyparison of these two procedures has not yet been attenpted. However, a recent study by keans, Welker, and Isaacson (1969) indicates that the Effect of hippocampal disruption upon go-no go performance nay be response-specific. Although it is typically reported that hippocanpectomy interferes with this behavior when exained in an instrumental paradign, such as an alleyway (Brown, Kaufean \& Harco, 1969), Nears et 2l. report that hippocampal ablations facilitate performence in this task when a bar press response is utilized. Findings such es these question the trans-situational nature of the pattern of behavioral dismuption observed following hippocanpal destruction and, consequently, any formulation which attenpts to account for these effects with global concepts 
such as "persereration," "gating," or "inhibition" without fusther resinement or gualification.

The third najor difference between this and contenporary in vestigations of the role of the hippocanpus in discrinination learning inrolves the schecules of reinforcenent associated with the two to-bediscriminated responses. The research reported previously has typically provided contimuous reinforcencht for "correct" responses and witheld remporcement for "incorrect" responses. In the present study concurrent operauts were utilized: Both responses vere reinforced, one on en FR 5 schelule and the other on an FR 9 schelule, and the fornation of the discrimination was based on a relative, rather than atsulute, differentiel in reinforcenent density. The experizental aralysis of cozcurrent ratio schedules indicates that with unequal FR requirements, responding tends to be caintaired only by the schedule with the saller FR requirezent; with equal fR requireants, responding can be maintafred by either one, and shifing from one schedule to the second occasionally occurs (Catania, 1966, Ferrnstein, 1958). In a study wich is only supericially comparable to the one reported here, Douglas and Pribrem (1966) examined the effects of probabilistic resinforcenent mon the formation of a discrininated panel press in moziteys. As in the present study the discrimination rested upon a relative differential in reinforcenent density; one response vas reinforced $70 \%$ of the time and the second reinforced $30 \%$ of the time. Their results, in contrast to those of the present study, indicated that hippocanpectogized. Ss are reterded uith respect to control Ss 
in their ebility to acquire a discrinination undes such conditions. Un fortunately, no data are presented on the perforance of these $\mathrm{S} s$ in discinination reversai. The reasons for these apparenty contradictory findings are unknom, but these studios roveal that insufficient attention has been directed tovards an elaboration of the esfects of schedules of reinforcement on discrimination formation and reversal in hippocampectonized $\underline{S}$.

Another difference between this and other studies of hippocanpal function involves the spacing of test trials. Host research in this area has employed a discrete trial procejure and the related technique of massei training trials during each daily exporinental session. In the present study the equivalent of test trials, the five dinute freechoice perjods, were widely spaced for they occurped at the baginning ô each daily experimental session. No drect evidence is avajiable concerning tho esfect of this factor on discrimination learning and reversel in hippocampectomized Ss. Hovever, there is evidence that the interval betreen trials does influence the behaviopal effects of hippocompal disruption. As reported previously, Kirkby, Stein, Kimbie and Kimble (1967) have dezonstrated that the lack of Twaze spontaneous e.lternation commonly reported in hippocampal Ss can be reestablished by lengthening the intertrial interval from 50 seconds to 10 minutes. Although their explanation of this phenomenon, a posinlated lesioninduced reduced inforcation acquisition rate, has been generally abandoned on the prenise that such preparations do not shou deficits in a number of alternative learning tasks, no adequate explanation has been 
formulated. Inttie os no additional research has been directed towards an anderstardizg of this finding, and until this phenomenon is investigated in greater detall such an explanation of the results of the present experiment connot be fully evaluated.

L fifth major departure of this experinent ralative to previous ressarch is tite utilization of a forced training technique. As a furction of fulfilling the requirenents of the response-reinforcement contingencies, this procezure insured that each $\underline{S}$ was fully exposed to the conditions of reinforcenent throughout both acquisition and retersal training. In adation, it can be assuned that this innotation most probably eaintained the strength of the FR 9 response at a relatively higier level then discrimination studies which have not employed forcez training on, and reinforcement of the "incorrect" response. Isascson, OIton, Eauer and Suat (1966) present evidence which indicates that the hippocerpally lesioned S's inability to withold a response in the passive avoidance task is directly related to the strengtiv of that response. It is also possible that the ease with which hipoocanpectomized Ss can inhibit one response and initiate an elternative is dependent upon the relative strength, or probability, of those two responses.

These findings, which demonstrate that hippocampal Ss are capable of inhbiting an established response and initiating another, stand in narked contrast to the bulk of the data on the performance of such Ss when feced with similar tasks. It is not surprising that task variables, sore of which heve been discussed above, rave the potential to profoundly influence the behavioral effect of physiological nanipulations. What is surprising is that no concerted effort has been made 
to explain such findings vithin the contexts of present forwlations of hippocampl function, or to revise these forwulations so that they noy incorporate these results. All too often findings such as have been discussed here are neglected or dismissed as aberrent. Perhaps a detailod exenination of the namer in which cxperimental manpulations can change or counteract the effects of pligsiological menipulations vill proride increasol insight into the role of reurophysiological systens in the intact organisn.

The unexpected facilitation of discrinination reversal perfordance resulting fron the neocortical damage sustained by the control Ss is nost likely attributable to uncontrolled position preferences, as vas discussed previousiy. Other experimentation on the effects of hippocangal ablation has typically inrolved analogous neocortically lesioned control Ss, and has regularly reported that such Ss do not differ from their unoperated counterparts. There are exceptions to this however, for Heans, ot 2. . (1969) have found that destruction of the noocortex operlying the hippocarpus leads to a retardation of performance in the go nomgo task; and Olton and Isaacson (1967) have reported that damage of this area, as vell as this area plus the hippocampus, lengthens response latencies in aroidance and escape tashs.

In the present experiment neocortical destruction involved considerable portions of the rat neocortex comparable to Broadman's area 7, which is inrolved in somesthesis, particularly the integration of information on weight and the state of muscles and joints; areas 17 
and 18, the visual projection and association areas, respectively; area 25, the entorininel cortex; and area 37 , which receives somesthetic and optic association fibers and, in men, is thought to be involved in the recognition of body inage, individuality and continuity of personality, and of the self in relation to the environment (Kreis, 1957). Since a considerable portion of the hippocampal research has involved sowe camage of these areas it is possible that comonly obm served hippocanpal lesion deficits are in actuality a function ô an interaction of the hippocampus and the neocortex winch overlies it. Within this context, Douglas (1967) has observed that electrolytic lesions restricted to the hippocarnous frequently do not produce the deficits seen in ablation studies involving neocontical destruction. It is also possible that tie facilitated perfortance shown by the hippocarpectorized Ss in the present study is fully accounted for by the effects of neocorical destruction. Questions such as these point to the relative prinitiveness of our understanding of the role of the hippocampus in behavior, and to the importance of further research in this area. 


\section{RTFERERTCES}

Adey, H. R. Studies of hippocenpel electrical activity during approach learming. In J. F. Delaifresnaye (EA.), Brain nechanisas in Jearning: Oxford: Blackell, 1961, pp. $5,7-533$.

Allen, $W$. F. Effect of ablating the frontal lobes, hippocami, and occipitcwarieto temporal (excoping pyriform arcas) lobes on positive and negaive olfactory conditioned reflexes. Americ Journal of Physiolost, 1940, 128, 754-771.

Allen, $\mathrm{H} . \mathrm{F}$. Effect of ablating the piroformacingdaloid areas and hippocerpj on positive and negative olfactory differentiation. Anerican Journal of Physiology, 1941, 132, 81-.92.

Boitano, J. J., \&: Iscacson, R. I. Effects of variation in shockintensity on the bebavios of dorsal-hipoocempectomized rats in tro passive aroidu ce situations. Anericen Joumal of Physiono, 1966, 80, 73-80.

Brom, I. S., Eaurman, P. Go \& Varco, I. A. The hippocempus and response perscreration in the cat. Broin Research, 1969, $12,86-98$.

Cajal, S. R. Y. Strdies on the cerebral cortex. Fol. 11. Iimbic structures (Trans. by L. ho Kraft). Chicago: Year Eook, 1955 .

Catanie, C. A. Concurrent operant. In W. K. Honis̃, (Ed.), Operant behavior; Areas of lesearch and aoplication. New Yor's: Appleton - Century - Crosts, 1966, pp. 213-270.

Clark, C. V. H., \&: Isaacson, R. I. Effect of bilateral hippocarpal ablation on DRL perfornance. Journal of Comoarative and Physjolosical PS7cholosy, 1965, 59, 137-140.

Correll, R. E. The effect of bilateral hippocanal stimulation on the acquisition and extinction of an instrumental response. Journal of Comorative and Physiological Psychology, 1957, 50, 624.629.

Devson, J.H., III, Nobel, K. H. \& Pribram, K. H. Corticofugal influcree of cochlcar mucleus of the cat: Some effects of ablation of insular-tezporal cortex. Brain Research, 1966, 2, $151-159$. 
Douglas, R. J. The hippotmpus and bohavior. Psycholosical Eulletin, $1967,67,416 \mathrm{~cm}, 42$.

Douglas, R. J., \& Pribran, K. H. Leaming and liabic lesions. Neuroosycholoria, $1966,4,197-220$.

Filen, P., \& Wilson, A. S. Persoveration in the rat following hippow campal lesions. Expeririental Neurolosy, 1963, 8, 310-317.

Feloman, S. Heurophysiological mechanisms and notifying afferent hypothalamowippocampal conjuction. Experinental Neurology, $1962,5,269-291$.

Gloor, P. Amygdala. In J. Field (Ea.) Hendbook of phys10lopy. Vol.2. Neurophysiology. Vashington, D. C.: American Physiological society, 1960, pp. 1395-1420.

Grastyan, E. \& Kermos, G. The influence of hippocempal lesions on sinple and delaying instrumental conditioned reflexes. In P. Passouant (Ed.), Prysiologia de I'hipoocampe, 1962, pp. 225-239.

Green, J. D. The hippocarpus. Physiological Reviev, 1964, 44, 561-608. Grecn, J. D. \& Adey, it. R. Electrophysiological studies of hippocamal connections and excitability. Blectroencephalosrachy and Cinicel Neuroohysiology, 1956, $1,245-262$.

Green, J. D., \& Arduini, A. Hippocampal electrical activity in erousal. Journal of Neurophiysiolooy, 1954, 17, 533-55?.

Herrnstein, R. J. Some factors influencing behavior in a two-response situation. Transactions of the liev York Acadeny of Sciences, $1958,21,35=45$.

Hirano, T. Effects of hippocampal electrical sirmlation on menory consolidation. Psychologia, 1966, 2, 63-75.

Hostetter, Gayle, \& Thomas, G. J. Evaluation of enhanced thignotaxis as a condition of inpaired vaze leaming by rats vith hippocanpal lesions. Joumal of Comparative and Physiological Psychologt, $1967,63,105-110$.

Isaacson, R. L., Douglas, R. J. \& Noore, K. Y. The effect of redical hippocaripal ablation on acquisition $\hat{i}$ avoidance response. Journal of Comnarative and Phrsiological Psychology, 1961, 54, $625-628$.

Isaacson, R. I., Olton, D. S., Bauer, B., \& Swart, P. The effect of the nuber of training trials on the deficit in jassive avoldance behavior in the hippocanpectomized rat. Paper read at Hidiestern Psychological Association, Chicago, 1966. 
Iscacson, R. I. \& \& Hirelejen, H. O. Hippoconal ablation and passive avoidance. Science, 1962, 133, 1104-1106.

Jasraid, I. Ee Bahavior of hippocampal lesioned rats in hone came and norel situations. Physiolory ard Pehavior, 1968, 3, 65-70.

Jerrard, L. E. \& Isvacson, R. I. Hippocenyal ablation in rats: Erfects of intertrial interval. Nature, 1965, 2.07, 109-110.

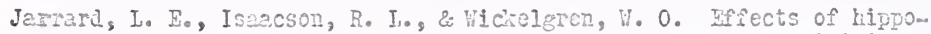
carpal ablation and intertrial interval on runvay acquisition and extinction. Jourm of Conarative end Fhrsiological Psycholoy, $1964,5 ?, 42-44$.

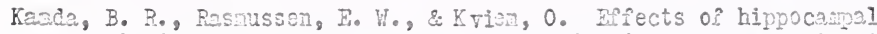
lesions on maze learning and retention in rats. Froerigental Neuro1cor, 1961, 3, 333-355.

Kaplen, J. I. Inhibitory reactions in rats uith bilateral hippocampal lesions. Processirs of the 75 th Arrual Conrention of the

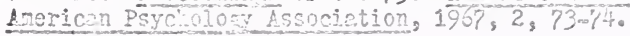

Kieble, D. P. The eifects of bilatercl hippocentpl losions in rats. Journa i of Comarative end Physiolczicai Psycholoy, 1963, 56, $273-283$.

Kinble, D. P., z Kimble, R. J. Hippocandectong and response perseveretion in the rat. Joum 1 of Congratite and Physiological Psychology, 1965, 60, 47 4-756.

Kieble, D. P., \& Zack, S. Olfactory discrimination in rats usth hippocampal lesions. Psvchononics Science, 1967, 8, 211-212.

Kimble, D. P., Kirkby, R. J., \& Steln, D. G. Response perseveration interpretation of rassive avoidance deficits in hippocampectonized rats. Joumel of Conrazative and Physiolosical Psycholosy, 1966, $61,141-143$.

Kieble, G. A. Hilered and Marquis conditioning and learning. Neu York: Appleton-Century-Crofts, Inc, 1961.

Kizura, D. Effects of selective hippocantpal damage on avoldance behavior in the rat. Canadian Journal of Psycholory, 1958, 12, 213-218.

Kirliby, R. J., Stein, D. G., Kimble, Recva J., \& Kinble, D. P. Effects of hippocanpal lesions and curation of sensory input on spontancous alternation. Joumal of Comarative and Physiological Psycholocz, 1967, 64, 342-345. 
Kluver, H., \& Eucy: P. C. Prelininary avalysis of functions of the temporal lobes in zontreys. Archives of Neurolosy and Psychiatry, 1939, 쓰, 979-1000.

Kries, W. J. S. Erain mecinnisas in diachrome. Bloomington, Illinois: Pantazraph Printirz Co., 195 ?

Kvien, O., Seteklier, J., \& Keada, B. R. Differential effects of hippocampal lesions on caze anl passive aroidance lcarning in rats. Exparinenta? IEuroloy, 1964, 2, 59-72。

Larrence, D. E. \& Festinoer, Ir Deterrents and reinforcemont. The psychology of insusicient remerd. Stanford: Stanford Uniterity Press, 1962.

Leaton, R. T. Exploratory behavior in rats with hippocenpal lesions. $\frac{\text { Journal of Cotnarative and Fhys }}{325-330 \text {. }}$

Nacintosh, N. J. Selective attention in aninal discrinination learning. Psychological Fulletin, 1965, 64, 124-150.

Hacintosh, I. J. The effects of overtraining on a reversal and a nonrevarsal silift. Journal of Connzative and Physiological Psycholory, 1962, 55, 555-559.

Nactean, P. D. The limbic system and its hippocamoal foriation: Studies in animals and their possible application to man.

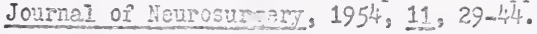

Haciean, P. D. The linbic system ('visceral brain') and enotional. behavior. Archizes of Neurological Psychiatry, 1955. 23, 130-134.

Maclean, P. D. Chemical and electrical stinulation of the hippocampus in unrestrained ani-als. American Medical Association Archives of licurolosy and Psjchiatry, 1957, 78, 1130142.

Naclean, P. D. Contrasting functions of limbic and reocortical systems of the brain and their relevance to psychophysiological aspects of medicine. Americar Journal of Medicine, 1958, 25, 611-626.

HcNew, J., \& Thoupson, Ro Role of the linbic system in active and passive aroidance conditioning in the rat. Journal of Comarative and Physiological Psychology, 1966, 61, 173-180.

Means, I. H., Walker, D. H. \& Isascson, R. I. Facilitated single elternation gomo go performance following hippocampectomy in rat. Paper presented at the meeting of the Psychononic society, St. Ionis, Hoveuber, 1969. 
Meissner, W. Hippocarpal functions in learning. Journal of Psychistric Reseren, 1966, $4,235-304$ 。

Niki, H. The effects of hippocampal abletion on the bahavior in the rat. Japanese Psycholo ical Research, 1962, 4, 139-153.

Niki, H. The efiects of hippocanpal ablation on the inhibitory conirol of operant benavior in the rat. Javanese Psycholorical Research, 1965, 2, 126-137.

0lton, D. So \& Isoacson, R. L. Hippocampal lesions and active aroilance. Physiology and Bohavior, 1967, 3, 719m724.

Papez, J. W. A propozed nechnisn of euotion. Archives of licurology and Psychiatry, 1937, 33, r25-743.

Pellegrino, I. J. \& Cushran, A. J. A stereotaxic atlas ô the rat brain. Nev York: Appleton Centuryecrots, 1967.

Peretz, F. Fxtinction of a foodmeinforced response in hipoocampectorized cats. Journal of Comprative and Physiological Psycholom,
1965, 60, $182-185$.

Pribrat, K. H. The conestic syodromes: Disturbances in coding? In E. R. John (tid.), The pethology of nevory. Yev York: Acciejtc Press, 1969, pp. 127-15\%.

Pabols, B. H. Jr. The facilitation of visual and seatial discrialnation reversal by overlearning. Jourmi of Comoarative and Physio. lorical Psycholosys 1956, $19,243=240$.

Rabe, Ausme. Discrimination reversal deficit from hippocampal stinulation in the rat. Journal of Psycinological Studies, 1963, 14,
$139-150$.

Raphelson, A. Co, Isascson, R. I., \& Douglas, R. J. The effect of limbic danage on the retention and performance of a runvay response. Nouropsychologia, 1966, 4, 253-264.

Reid, L. S. The developzent of noncontinuity behsvior through continuity learning. Journel of Experimental Psycholog, 1953, 46, 107-112.

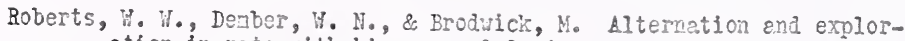
ation in rats with hippocanpal lesions. Journal of Comparative and Physiological Psycholosy, 1962, 55, 695-700.

Schraltz, L. V., \& Isacson, R. L. Fiffect of bilateral hippocampal destruction on the ecquisition and extinction of an operant response. Physiolory and Poharior, 1967, 2, 291-298. 
Scimaltz, Lo, \& Isacson, R. L. The effects of prelininary training condistons under D.T perionance in the hippocanpectonized rat. Physiolosy and Behrvior, 1966, 1, 175-182.

Siegel, S. Nemorratric statistics for the behavioral sciences. Nev York: MCGPCWHII, 1950.

Splrilli, D. I., \& Pribram, K. H. Changes in visual recovery funciions produced by temporal 100 e stimulation in nonkeys. Electroencepla lo rraphy and Clinical Neurophysioloy, 1966, 20 , $44-19$.

Struf, C. H. Drig action on the electrical activity of the hippocanpus. Intermational Pevier of Feurolosy, 1965, 8, 77-133.

Stutz, R. Ko, \& Rocklin, K. W. Cingulete and fornix lesions: Effects on twa types of reversal learning. Journal of Convarative and Physic: ooj.cal Psychology, 1968, 65, 520-523.

Sutan, H. G. The function of the brain in olfaction. The effects of large cortical lesions on olfactory discrimination. gmerican Journet of PLYsioloet, 1935, 111, 357-262.

Swam, H. G. The function of the brain in olfaction. II. The results of destruction of olfactory and other nervous stiuctures upon the discrimination of odors. Journal of Comarative reurolosy, 1934. 59, 175-201.

Swanson, A. Heg \& Isazcson, R. I. Hippocanpal ablation and performanco during Withdranal of reinforcement. Jourmol of Comcarative and Phys 1010 icel Psycholory, 1967, 64, in press.

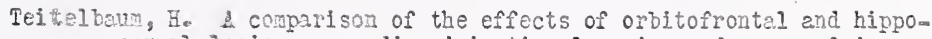
carpal lesions upoin discrimination learning and reversal in the cac. Experinental Neurology, 1964, 2, 452-462.

Teitelbaur, H. \& Milner, P. Actirity changes following partial hippocempal lesions in rats. Journal of Comparative and Physiolosical Psycholosy, 1963, 56, 284-289.

Thompson, P., \& Ionger, S. K. Dericits in position reversal learing following lesions of the limbic system. Journal of Comparative and Physiolorical Psychology, 1953, 56, 987-995.

Wagzer, A. R. overtraining and frustration. Psycholosical Renorts, $1963,13,717-718$.

Webster, D. B. \& Voneida, T. J. Learning deficits following hippow campal lesions in solit-brain cats. Experimental Neurology, $1964,20,170-182$. 
Winer, B. J. Statisticn princinles in exoerinentel desinn. Wev Yor:: NCGreNarill, 1962 .

Winocur, G., \& Mills, J. A. Hippocampus and septum in response

inhibition. Joumal of Comnarative and Physiologicel Psycholoci, 1969, 67, 352-35\%. 


\section{BIOGRAPHICAI SKETCH}

Michael Amold Milan vas torn on January 25, 1938, at New York, New York. He attended public school in New York state and graduated from Fayetteville..':anlius High School, Fayetteville, Now York, in June, 1956. In $19 \mathrm{y}, 1960$, he receivet the degree of Bachelor of Arts from Syracuse University. From 1960 until 1962, he served in the Adjutant General Corps of the United. States Aray. Following his ralease from the Aray he was eaployed as a psychological research assistant with the Veteran's Adrinistration Eospital in Syracuse, Ner York. In Septenber, 1963, he enrolled in the graduate school of the University of Florida and received the Naster of Arts degree in December, 1965. He serveü as a research assistent for Dr. H. S. Pennypacker and as an interid instructor with the Departrent of Psycholosy whie Eatriculating for the Doctor of Philosophy degree in psychology. 
This disseration was prepared undes the direction of the chairman of the candidate's supervisory comittee and has been approved by ali meniers of that comittee. It was subritted to the Dean of the Coliege of frots and Sciences and to the Graduate council, and ras approred as partiol fulfillment of the requirements for the degree of Doctor of Flis osophy.

June, 1970

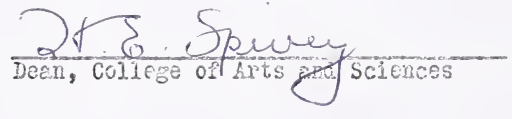

Lean, Graducte Scrool

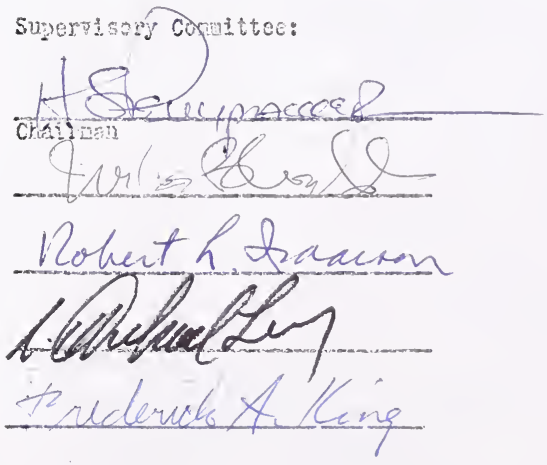


$7714 \mathrm{~B}$ 